\title{
Marine crude-oil biodegradation: a central role for interspecies interactions
}

Terry J McGenity*, Benjamin D Folwell, Boyd A McKew and Gbemisola O Sanni

\begin{abstract}
The marine environment is highly susceptible to pollution by petroleum, and so it is important to understand how microorganisms degrade hydrocarbons, and thereby mitigate ecosystem damage. Our understanding about the ecology, physiology, biochemistry and genetics of oil-degrading bacteria and fungi has increased greatly in recent decades; however, individual populations of microbes do not function alone in nature. The diverse array of hydrocarbons present in crude oil requires resource partitioning by microbial populations, and microbial modification of oil components and the surrounding environment will lead to temporal succession. But even when just one type of hydrocarbon is present, a network of direct and indirect interactions within and between species is observed. In this review we consider competition for resources, but focus on some of the key cooperative interactions: consumption of metabolites, biosurfactant production, provision of oxygen and fixed nitrogen. The emphasis is largely on aerobic processes, and especially interactions between bacteria, fungi and microalgae. The self-construction of a functioning community is central to microbial success, and learning how such "microbial modules" interact will be pivotal to enhancing biotechnological processes, including the bioremediation of hydrocarbons.
\end{abstract}

Keywords: Hydrocarbon, Crude oil, Salt marsh, Marine microbiology, Biodegradation, Bioremediation, Microbial interactions, Biogeochemistry, Alcanivorax

\section{The problem of marine oil pollution}

Our seas, oceans and coastal zones are under great stress; and pollution, particularly by crude oil, remains a major threat to the sustainability of planet Earth [1]. An estimated 1.3 million tonnes of petroleum enters the marine environment each year [2]. Acute pollution incidents cause great public concern, notably $\sim 600,000$ tonnes of crude oil released after the Deepwater Horizon explosion in the Gulf of Mexico [3] and 63,000 tonnes from the Prestige oiltanker [4] off the coast of north-west Spain. The fate of crude oil spilled at sea (Figure 1) depends on both the prevailing weather and the composition of the oil; but its environmental impact is exacerbated on reaching the shoreline, especially in low-energy habitats, such as lagoons and salt marshes. Acute pollution events can result in mass mortality; for example, more than $66 \%$ of total species richness (including polychaetes, molluscs, crustaceans and insects) was lost in the worst affected beaches following the

\footnotetext{
*Correspondence: TJMcGen@Essex.ac.uk

School of Biological Sciences, University of Essex, Wivenhoe Park, Colchester CO4 3SQ, UK
}

Prestige spill [5]. Hydrocarbons also contaminate the feathers and fur of marine birds and mammals, resulting in the loss of hydrophobic properties, leading to death from hypothermia [6], or lethal doses following ingestion of oil during preening.

Moreover, the impact of hydrocarbons, especially polycyclic aromatic hydrocarbons (PAHs), on wildlife and fisheries may be long-lasting; for example the Fisheries Exclusion Zone imposed after the Braer spill (Shetland Islands, United Kingdom, 1993) due to contaminated fish and shellfish, remained in place for over 6 years. Chronic pollution can cause physiological or behavioural damage at sub-lethal concentrations; and genetic damage and decreases in both growth and fecundity have been observed in fish $[7,8]$. Deep-sea sediments and associated biota are also chronically affected by drilling, which deposits vast amounts of oil-contaminated drill cuttings on the seafloor [9]. Even when oil-contaminated coastal sediments appear to be clean (e.g. Prince William Sound that was contaminated by the Exxon Valdez spill in 1989), toxic oil components, such as high molecular 


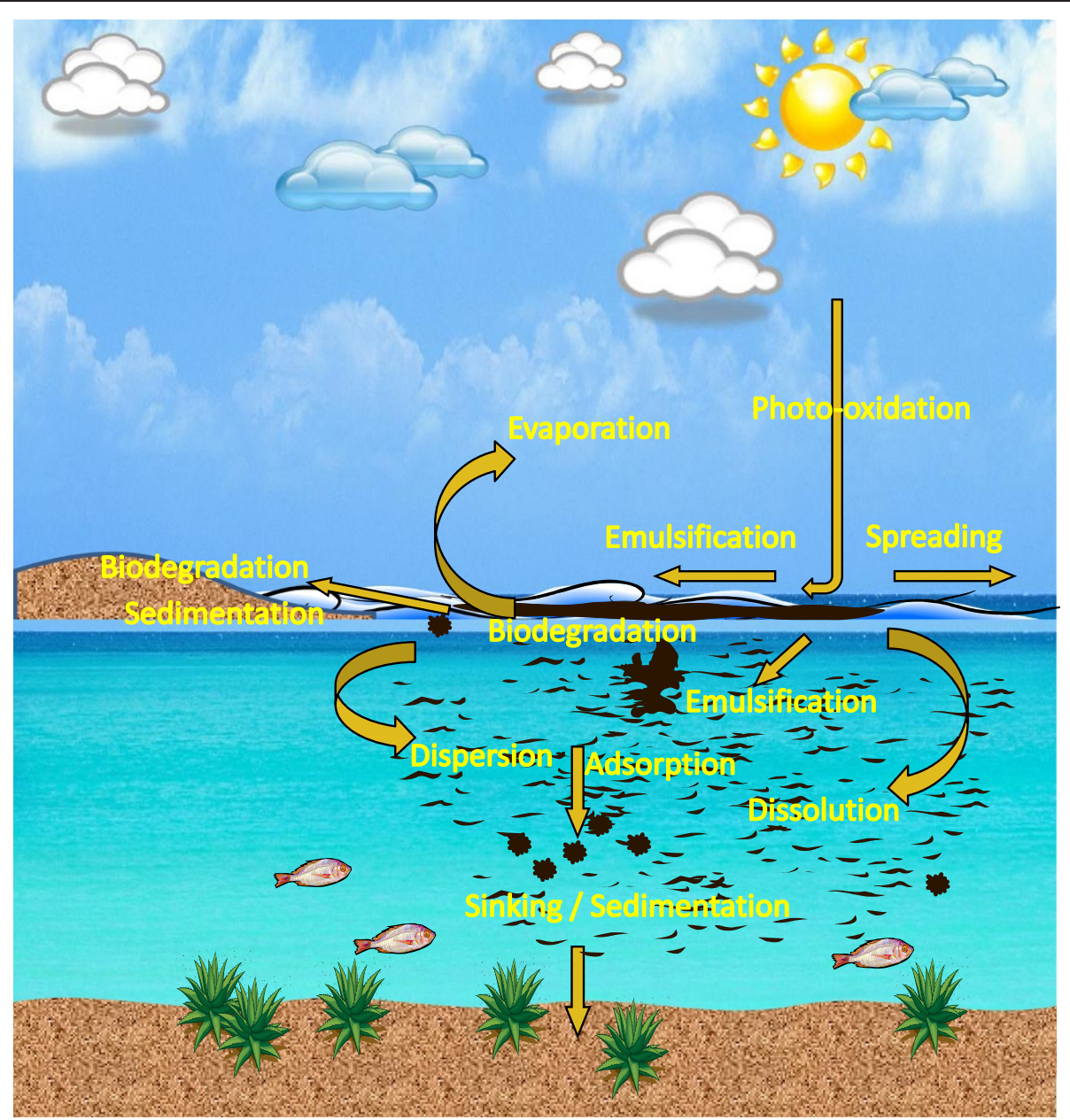

Figure 1 Fate of a marine oil spill (for a more detailed explanation, see http://www.itopf.com/marine-spills/fate/weathering-process/). Spreading is affected by the action of winds, waves, water currents, oil type and temperature, and enhances evaporation of the volatile fractions such as low molecular weight alkanes and monoaromatic hydrocarbons. Spilt oil is broken into droplets and dispersed through the water column, enhancing the biodegradation of hydrocarbons and dissolution of water-soluble fractions of oil. Turbulent seas cause water droplets to be suspended in the oil, resulting in water-in-oil emulsions, alternatively known as chocolate mousse, which is difficult to degrade because of its high viscosity and reduced surface area. Photo-oxidation is the process by which hydrocarbons, especially PAHs, react with oxygen in the presence of sunlight, resulting in structural changes that can on the one hand lead to increased water solubility or, conversely, increased recalcitrance to biodegradation. Sedimentation will general only occur when oil adsorbs to particles owing to nearly all crude oils having a lower density than seawater.

weight (HMW) PAHs, may remain buried and sorbed to sediment particles, and can be released to the environment by bioturbation or human activities such as dredging [10].

Crude oil is a natural, heterogeneous mixture of hydrocarbons, with potentially 20,000 chemical components [11], consisting mainly of alkanes with different chain lengths and branch points, cycloalkanes, mono-aromatic and polycyclic aromatic hydrocarbons (Figure 2; [12]). Some compounds contain nitrogen, sulfur and oxygen [12]; while trace amounts of phosphorus, and heavy metals such as nickel and vanadium are also found [13]. Its composition varies widely, and each oil component has different physico-chemical properties, including viscosity, solubility and capacity to absorb (Table 1), as well as varying in its bioavailability and toxicity. Crude oil, released naturally from the geosphere to the biosphere (e.g. from cold seeps [14]) may supply up to half of the oil in the sea [2]. Although hydrocarbons are relatively stable molecules, their "fuel value" and presence in the environment for millions of years have led to the evolution of many microbes able to activate and use them as a major or sole source of carbon and energy, including at least 175 genera of Bacteria [15]. Several haloarchaeal genera [16] and many Eukarya can grow on or transform hydrocarbons [17]. Biodegradation of crude oil to carbon dioxide and water is the major process by which hydrocarbon-contaminated environments are remediated. 


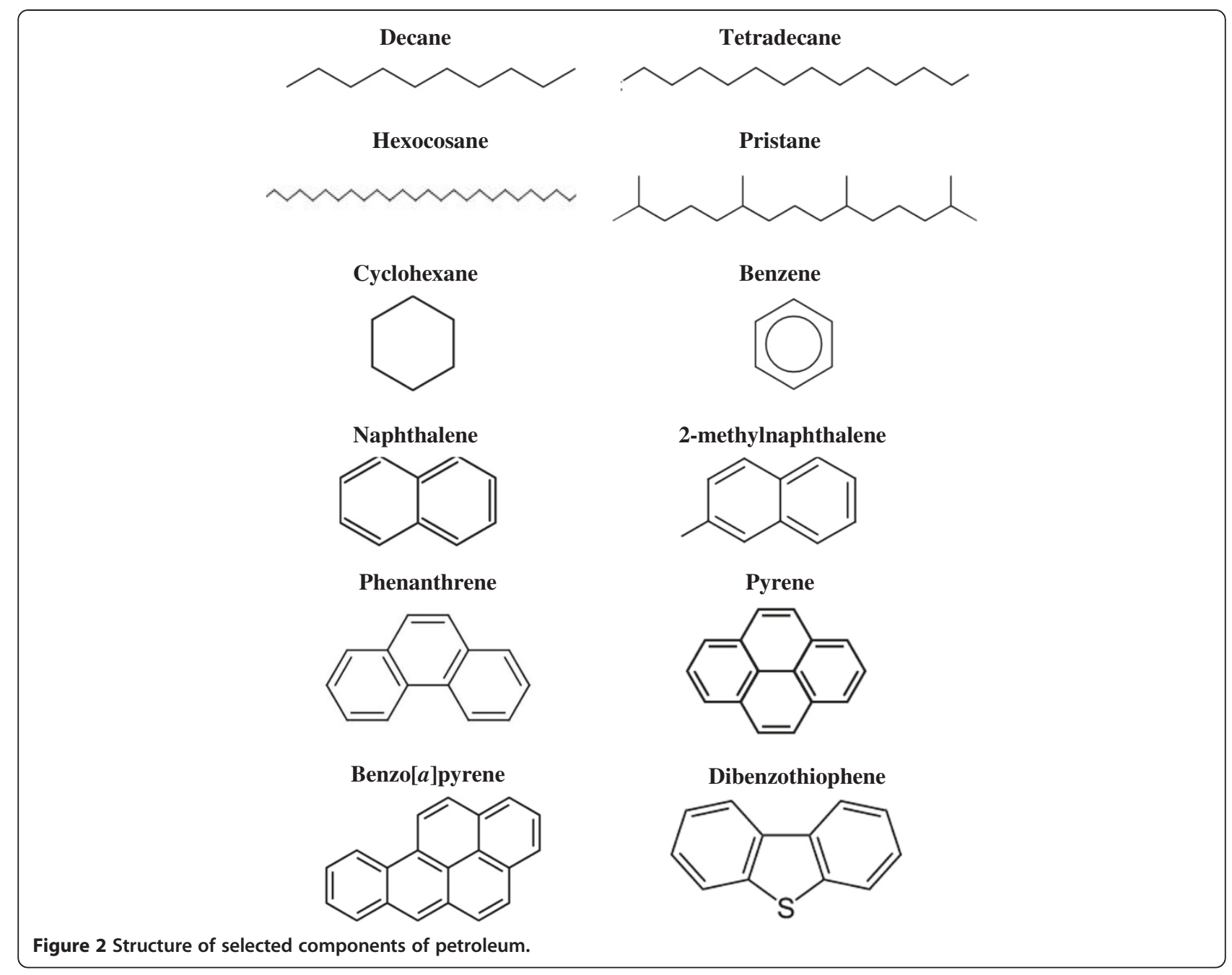

Figure 2 Structure of selected components of petroleum.

Table 1 Selected hydrocarbons and their solubility in deionised water at $25^{\circ} \mathrm{C}$ and hydrophobicity indicated as Log $\mathrm{K}_{\text {ow }}$

\begin{tabular}{lll}
\hline Compound & Solubility $\left(\mathbf{m g ~ L}^{-1}\right)$ & Log $\mathbf{K}_{\mathbf{o w}}$ \\
\hline Decane & 0.091 & 6.1 \\
Tetradecane & 0.009 & 7.2 \\
Hexocosane & $\mathrm{NA}$ & 14.7 \\
Pristane & $5 \times 10^{-5}$ & 11.4 \\
Cyclohexane & 43.0 & 3.2 \\
Dibenzothiophene & 2.41 & 4.3 \\
Benzene & 1790 & 2.1 \\
Naphthalene & 31.7 & 3.3 \\
2-methylnaphthalene & 24.6 & 3.9 \\
Phenanthrene & 1.29 & 4.5 \\
Pyrene & 0.14 & 5.3 \\
Benzo[a]pyrene & 0.004 & 6.0 \\
\hline
\end{tabular}

The principal marine hydrocarbon degraders

The starting point in elucidating potential complex interactions involved in hydrocarbon biodegradation is to identify the microbes primarily responsible for biodegradation, and their catabolic pathways. It has long been known that the enzymatic activation of hydrocarbons by oxygen is a pivotal step in their biodegradation, and several mechanisms have been elucidated for aromatic $[12,18,19]$ and aliphatic $[12,20]$ compounds. However, our understanding of the catabolic processes for HMW PAHs [21] and anaerobic activation mechanisms and pathways, e.g. fumarate addition, carboxylation and $\mathrm{O}_{2}$ independent hydroxylation, have emerged only recently [22-25].

The microbial response to an oil spill at sea is dependent on numerous factors, including the oil composition and degree of weathering, as well as environmental conditions, particularly temperature and nutrient concentrations. Nevertheless, there are some typical patterns; most notable is the large increase in abundance of Alcanivorax spp., which degrade straight-chain and branched alkanes [26- 
32], followed by Cycloclasticus spp., which degrade PAHs [26-30,33-36].

Since the cultivation of Alcanivorax borkumensis [37], functional genomic, biochemical and physiological analyses have revealed the underlying basis of its success [28,38-40]. While it lacks catabolic versatility, utilising alkanes almost exclusively as carbon and energy sources, it has multiple alkane-catabolism pathways, with key enzymes including alkane hydoxylases (a non-haem diiron monooxygenase; AlkB1 and AlkB2) and three cytochrome P450-dependent alkane monooxygenases [38]. Their relative expression is influenced by the type of alkane supplied as carbon and energy source and phase of growth [38]. Alcanivorax borkumensis also possesses a multitude of other adaptations to access oil (e.g. synthesis of emulsifiers and biofilm formation [38]) and to survive in open marine environments (e.g. scavenging nutrients and resistance to ultraviolet light $[38,40])$. Acinetobacter spp., which are commonly isolated from oil-contaminated marine environments [41], also have a diverse array of alkane hydroxylase systems enabling them to metabolize both short- and long-chain alkanes $[20,42]$. For example, Acinetobacter strain DSM 17874 contains a flavin-binding monooxygenase, AlmA, which allows it to utilize $\mathrm{C}_{32}$ and $\mathrm{C}_{36} n$-alkanes [43]. The $\operatorname{alm} A$ gene has also been found in Alcanivorax dieselolei B-5 and is induced by long-chain $n$-alkanes of $C_{22}-C_{36}$ [44]. A diverse array of alkB gene sequences, encoding alkane hydroxylase, has been detected in the environment $[45,46]$ and in a wide range of bacteria $[38,42,46]$, however Païssé et al. [47] argue that alkB expression may not always be a good indicator for microbial oil degradation, implying that we have not fully explored the gene diversity and/or that other hydrocarbon catabolic processes were prevalent in the environment under investigation.

In cold marine environments, the obligate alkanedegrading psychrophile, Oleispira, rather than Alcanivorax spp., are commonly associated with oil spills $[29,48]$; and Alcanivorax spp. are sometimes outcompeted by Thalassolituus spp. in temperate environments [34]. Such obligate hydrocarbon-degrading bacteria can constitute $90 \%$ of the microbial community in the vicinity of the oil spill and have a wide global distribution [28]. New genera of obligate alkane degraders are still being discovered, e.g. Oleibacter sp. $[31,49]$, and there are likely to be many more, such as the uncharacterised Oceanospirillales strain ME113 [50], which has been detected in abundance in other oil-rich marine environments [51,52].

The role of the generalists that degrade alkanes and/or PAHs as well as non-hydrocarbons is often overlooked, yet they can constitute a significant proportion of a hydrocarbon-degrading community. For example, Buchanan and Gonzalez [53] outline eight studies in which members of the Roseobacter lineage, which harbours a diversity of ring-hydroxylating dioxygenases and alkane hydroxylases, increase in abundance in hydrocarbonenriched marine waters. Other generalists, including Acinetobacter, Marinobacter, Pseudomonas and Rhodococcus spp. [54-57], contribute to hydrocarbon degradation. Sediments add to the complexity of identifying the main hydrocarbonoclastic microbes, but nearly all of the above genera are detected in the aerobic zone of marine sediments and presumed to be active in hydrocarbon degradation. It is important to recognise that within most of the genera labelled here as generalists (e.g. Marinobacter) there are many species, ranging from those that do not degrade hydrocarbons to specialists like Marinobacter hydrocarbonoclasticus, which almost exclusively utilises $n$ alkanes [56].

Although Cycloclasticus is frequently the main marine PAH-degrading microbe detected, many others from several tens of genera are known [15], and the underlying mechanisms of their interactions with, and degradation of PAHs are only beginning to be elucidated. For example, in San Diego Bay sediments, isolates able to grow on phenanthrene or chrysene were from the genera Vibrio, Marinobacter, Cycloclasticus, Pseudoalteromonas, Marinomonas and Halomonas [58]. Another marine specialist PAH degrader, named Porticoccus hydrocarbonoclasticus, was recently isolated [59], and strains of Microbacterium and Porphyrobacter, previously not known to be involved in PAH degradation, were isolated on benzo[a]pyrene after enriching for two years [60]. Based on DGGE analysis, Hilyard et al. [61] suggested that Planctomyces and Bacteroidetes were involved in PAH degradation, and many more species from diverse genera that are implicated in $\mathrm{PAH}$ degradation remain to be cultivated, particularly those growing on HMW PAHs.

Incubation of marine sediment in the presence of phenanthrene and bromodeoxyuridine (BDU), followed by analysis of BDU-labelled DNA, revealed a remarkable diversity of putative PAH degraders belonging to the genera Exiguobacterium, Shewanella, Methylomonas, Pseudomonas, Bacteroides, as well as Deltaproteobacteria and Gammaproteobacteria that were not closely related to cultivated organisms [62]. Some were also cultivated, including a novel Exiguobacterium strain, but the rest remain to be grown [62]. Similarly, stable-isotope probing (SIP) of DNA was used to identify the involvement of a novel clade of Rhodobacteraceae in biodegradation of low molecular weight (LMW) PAHs in marine algal blooms [63]. Obtaining pure cultures of the main microbes responsible for hydrocarbon biodegradation is no longer a prerequisite for their study, but it makes their investigation very much easier, allowing genomic, biochemical and physiological analyses that in turn can help to explain their in-situ function and interactions. It is also frequently their reliance on other microbes that prevents cultivation in the first instance, and growth in the proximity of microbes (or their 
diffusible products) from the same habitat [64] can be employed to improve recovery. Numerous other procedures can enhance cultivation [65], especially by increasing the bioavailability of hydrocarbons. Calvo et al. [66], for example, extracted extracellular polymeric substances (EPS) from Halomonas eurihalina, not a PAH-degrader, which enhanced the isolation of other microbes growing on PAHs.

\section{General considerations of microbial interactions}

A volume of $1 \mathrm{~mm}^{3}$ of surface seawater, approximately equivalent to the size of a poppy-seed, contains $\sim 600$ bacteria, 150 cyanobacteria, 9 small algae, <1 protozoan [67] and $\sim 10,000$ viruses [68]. Numerous ecophsyiological investigations [69] together with modelling the cooccurrence of bacterial phylotypes [70] reveal a network of direct and indirect interactions within and between species in seawater that are vital for maintaining the microbial loop that drives marine biogeochemical cycles [71]. Some interactions exist between spatially separated species that use soluble or volatile metabolites to transmit information; while other interactions involve species in very close proximity, either as a biofilm on the same particle or physically associated to one another. Grossart [69] noted that a chain of the marine diatom, Thalassiosira rotula, can host up to $10^{8}$ bacteria [72], while a single copepod can harbour up to $10^{9}$ bacteria [73]. Surprisingly, in many studies, the attached microbiota, which is numerically equivalent to the non-attached microbiota, is removed by pre-filtration [69], and so not considered.

Microbial communities from coastal sediments vary more from one location to another than those from open waters, and have much greater community evenness [74]. Moreover, in sediments, cells are much more concentrated, resulting in a greater likelihood of interactions, which becomes even more prevalent in biofilms where cells are more densely packed. Highly productive photosynthetic microbial mats develop at the watersediment interface. These multispecies biofilms consist of horizontally stratified layers with extremely steep gradients of light, redox potential, oxygen, sulfur species etc. The exceptionally high microbial diversity within a few microns covers a large range of metabolic groups (oxygenic and anoxygenic phototrophs, sulfate reducers, methanogens etc.) [75]. We are at an early stage in our understanding of communication mechanisms in each of these environments (open water, sediment and biofilms), where small molecules, either diffusing from cell to cell [76], or transported by vesicles [77] or via nanotubes bridging cells [78], elicit intra- and inter-species effects that could be antagonistic or beneficial.

Microbes exhibit all of the types of social behaviour (mutual benefit, selfishness, altruism and spite [79]) seen in multicellular organisms. However, it is often difficult to categorise such behaviour in complex multi-species natural environments, and so in this review we talk largely in terms of cooperation and competition, and how they are affected by hydrocarbons, and in turn influence their fate. Our knowledge gained from studying pure cultures of hydrocarbon degraders is important, but hydrocarbonoclastic bacteria rarely, if ever, function in isolation in nature. Therefore, a better understanding of crude-oil biodegradation, and thus the capability to more rationally remediate contaminated environments, requires us to consider the mechanisms of the interactions between different hydrocarbon-degrading microbes and with nondegrading organisms [27]. This review considers such interactions, with most emphasis on aerobic processes and interactions between phototrophic microalgae and hydrocarbonoclastic bacteria.

\section{Interactions between microbes during aerobic degradation of hydrocarbons}

When crude oil is added to seawater, the microbial community changes and consists of multiple co-existing species [80], which can be explained most simply by resource sharing. As indicated above, crude oil consists of a variety of chemically distinct hydrocarbons, which require specific mechanisms for activation and degradation. In seawater microcosms, each supplied with a different hydrocarbon, McKew et al. [34] observed that: 1) Alcanivorax dominated when the branched alkane, pristane, was supplied, but was not detected in other microcosms, 2) Cycloclasticus was dominant with most PAHs, but was undetected when fluorene was supplied, and 3) Thalassolituus was the dominant species when $n$-alkanes with 12 to 32 carbons were added, but was not detected when decane was the sole alkane added to seawater. Thus, it appears that the ability to be competitive in the marine / estuarine environment requires that hydrocarbonoclastic bacteria are relatively specialised. Probably the extra genetic and cellular load needed to allow bacteria to grow on a wider range of hydrocarbons would demand greater nutrient resources, making them less competitive overall, especially in oligotrophic oceans. This, in turn, requires the presence of a consortium of microbes for complete degradation of crude oil.

Competition for resources is also an important element of petroleum biodegradation: all known Alcanivorax spp. can degrade $n$-alkanes, yet in the above study [34] Thalassolituus out-competed Alcanivorax. Furthermore, in a follow-up study Alcanivorax was undetected in the microcosms to which Thalassolituus oleivorans had been added previously, whereas it grew in all other microcosms, though its abundance was negatively correlated with that of Thalassolituus [30]. The nature of this competition deserves more detailed study. It could simply be competition for common resources, such as nutrients, but the idea that Thalassolituus actively releases bioactive compounds 
to inhibit competitors must be considered. Nevertheless, as noted above, in most oil-amended experiments and environmental surveys Alcanivorax is the dominant microbe, so it is pertinent to consider whether it produces antibacterial molecules. Alcanivorax jadensis produces an antibiotic which has been termed "alcanivorone" [81], but the impact of this antibiotic on other microorganisms during hydrocarbon degradation is still unknown. In a twospecies experiment, Alcanivorax borkumensis outcompeted Acinetobacter venetianus, but the filtered spent medium from Alcanivorax borkumensis did not influence the growth of Acinetobacter venetianus, rather Hara et al. [82] proposed the former's ability to use branched alkanes as a key factor. However, such branched alkanes are a relatively minor component of crude oil, and so the extra carbon and energy available to Alcanivorax borkumensis may be just one of several possible explanations.

Even when a single hydrocarbon is added to seawater microcosms, multiple species are always detected $[34,36,80,83]$, and frequently mixed cultures outperform single species isolated from a consortium [83]. For example, the dominant benzo[a]pyrene-degrading bacteria from a marine enrichment were isolated, and faster degradation was seen when the three strains (Ochrabactrum, Stenotrophomonas and Pseudomonas spp.) were combined than when tested individually [84]. Both Cycloclasticus and Pseudomonas were abundant in estuarine waters enriched with naphthalene, but Pseudomonas appeared in the latter stages of the enrichment [36]. Perhaps the most compelling explanation for multiple species growing on one carbon and energy source, is that a measurable amount of the $\mathrm{PAH}$ is not completely oxidized to $\mathrm{CO}_{2}$ and $\mathrm{H}_{2} \mathrm{O}$ by one organism, resulting in oxidation products being liberated into the environment. Numerous microbes may take advantage of this so-called epimetabolome $[85,86]$ as sources of carbon and energy $[87,88]$.

It is becoming apparent that metabolite sharing is widespread in nature and in the laboratory as shown using auxotrophic mutants of Escherichia coli that complemented each other's growth by cross-feeding essential metabolites [89]. The cooperative behaviour of microbes to selfconstruct a functioning community is central to their success, and learning how such "microbial modules" interact will be pivotal to enhancing biotechnological processes, including the bioremediation of hydrocarbons. However, few studies have tracked the flow of hydrocarbon-derived metabolites between microbes in a consortium, and many interesting metabolites are transient and therefore difficult to detect. Pelz et al. [87] tracked the biodegradation of 4-chlorosalicylate through a three-member consortium of Pseudomonas MT1, Pseudomonas MT4 and Achromobacter MT3 using ${ }^{13} \mathrm{C}$-labelled substrates. Analysis revealed a network of carbon sharing: strain MT1, the only member able to degrade 4-chlorosalicylate, provided carbon skeletons to the other strains (MT3 and MT4), while they degraded toxic metabolites that inhibited strain MT1 if allowed to accumulate [87]. One of the toxic intermediates (4-chlorocatechol) was partially taken up by strain MT3 and further degraded [87]; and a proteomic and metabolite analysis of a co-culture of strains MT1 and MT3 revealed the importance of strain MT3, not only in consuming the toxic intermediate but also in reducing the degradation rate of the parent compound by strain MT1; both of which minimized the stress experienced by strain MT1 as judged by negligible detection of stress-response proteins in the mixed culture compared with the pure culture [90].

Reducing the stress imposed by metabolites may also be a typical feature in bacterial members of consortia degrading PAHs. However, our current knowledge of the catabolic routes for $\mathrm{PAH}$ degradation requires considerable development as diverse novel metabolites are produced by PAH-degrading microbes [43,91]; for example Cycloclasticus strain P1, derived from a deep-sea pyrenedegrading consortium, produced three metabolites, two of which could be identified as cyclopenta $[d, e, f]$ phenanthreone and 4-phenanthrenol [83]. These metabolites are unusual as they involve the creation of a pentagonal ring suggesting a novel catabolic pathway is adopted by strain P1 [83].

Chen and Aitken [92] showed that salicylate, an intermediate produced by a Pseudomonas sp. pre-grown on phenanthrene as a sole source of carbon and energy, induced production of a PAH dioxygenase leading to degradation of HMW PAHs that the isolate could not use for growth [92]. The importance of metabolites as inducers of co-metabolic degradation may be significant also in natural communities.

A wide variety of fungi are known to be important in initiating biodegradation of HMW PAHs in terrestrial environments by co-metabolism using a battery of enzymes (e.g. lignin peroxidases, manganese peroxidases, laccases and epoxide hydrolases) that probably evolved to breakdown other compounds such as lignin, but which fortuitously degrade PAHs [91,93-95]. Extracellular enzymes and radicals produced by ligninolytic fungi are not constrained by slow desorption and mass transfer which limit the activity of those microbes that need PAHs to enter the cell. Moreover, these metabolites are generally more polar, and so more bioavailable, than the parent compounds [96]. An increase in bioavailability of polar metabolites was demonstrated by experiments undertaken with the white rot fungus Bjerkandera strain BOS55 [97]. As a pure culture it was able to degrade $74 \%$ of ${ }^{14} \mathrm{C}$-benzo[a]pyrene but only produced a limited amount of ${ }^{14} \mathrm{CO}_{2}$. The addition of soil, sludge or LMW $\mathrm{PAH}$ enrichment cultures led to a rapid increase in ${ }^{14} \mathrm{CO}_{2}$ production as the polar metabolites produced by 
the fungus were mineralised, but only up to $34 \%$, indicating that some ${ }^{14} \mathrm{C}$ - benzo[a]pyrene fungal metabolites were readily biodegraded while others persisted [97]. This has also been demonstrated with fungal-bacterial cocultures containing the non-ligninolytic fungus Penicillium janthinelum VUO 10,201, which showed significant degradation of a range of HMW PAHs including pyrene and benzo $[a]$ pyrene compared with either the fungal or bacterial species incubated alone [98]. Twenty-five percent of benzo[a]pyrene was mineralised to $\mathrm{CO}_{2}$ over 49 days by the co-cultures, accompanied by the detection of transient intermediates [98].

Figure 3 provides a schematic illustration of some of the interactions involved in hydrocarbon biodegradation. When present in mixtures, PAHs have the capacity to negatively influence the rate and extent of biodegradation of other components in the mixture [99]. Some metabolites may not be degraded further in a particular environment (dead-end metabolites), and while they are usually less toxic than the parent compound, some are more toxic, and so it is important to monitor production of metabolites and the overall toxicity during bioremediation processes. For example, metabolites, such as pyrene-4,5-dione derived from pyrene transformation have the potential to accumulate in PAH-contaminated systems and significantly inhibit the biodegradation of other PAHs [100].

Although fungi are considered to be largely terrestrial, they have been found in marine mats [101] and it is known that many can function in saline conditions [102], but in general salt-adapted fungi have received little attention despite a potentially major role in coastal PAH degradation. The ubiquitous co-existence of bacteria and fungi in soil and sediments [103] and their known catabolic cooperation suggests that physical interactions between them may be of importance for PAH degradation. There is also evidence that filamentous fungal networks may facilitate the movement of hydrocarbon-degrading bacteria through soils and sediments - the so-called "fungal highway" - by providing continuous liquid films in which gradients of chemo-attractants can form and chemotactic swimming can take place, thus greatly increasing the accessibility to pollutants [104].

\section{Biosurfactants and the interactions between hydrocarbon-degrading microbes and their environment}

PAHs are usually found mixed with other organic pollutants (commonly petroleum and derived products) in contaminated sites, which may alter their fate and transport. This is of particular relevance when considering aged or weathered oils, in which PAHs will be less bioavailable because they are more effectively partitioned within the residual oil phase [105]. PAHs, particularly HMW PAHs, adsorb strongly to minerals and their associated organic matter [106], further diminishing their bioavailability. Owing to the low solubility and high levels of adsorption of PAHs, many microbes have evolved mechanisms to access them more readily. For

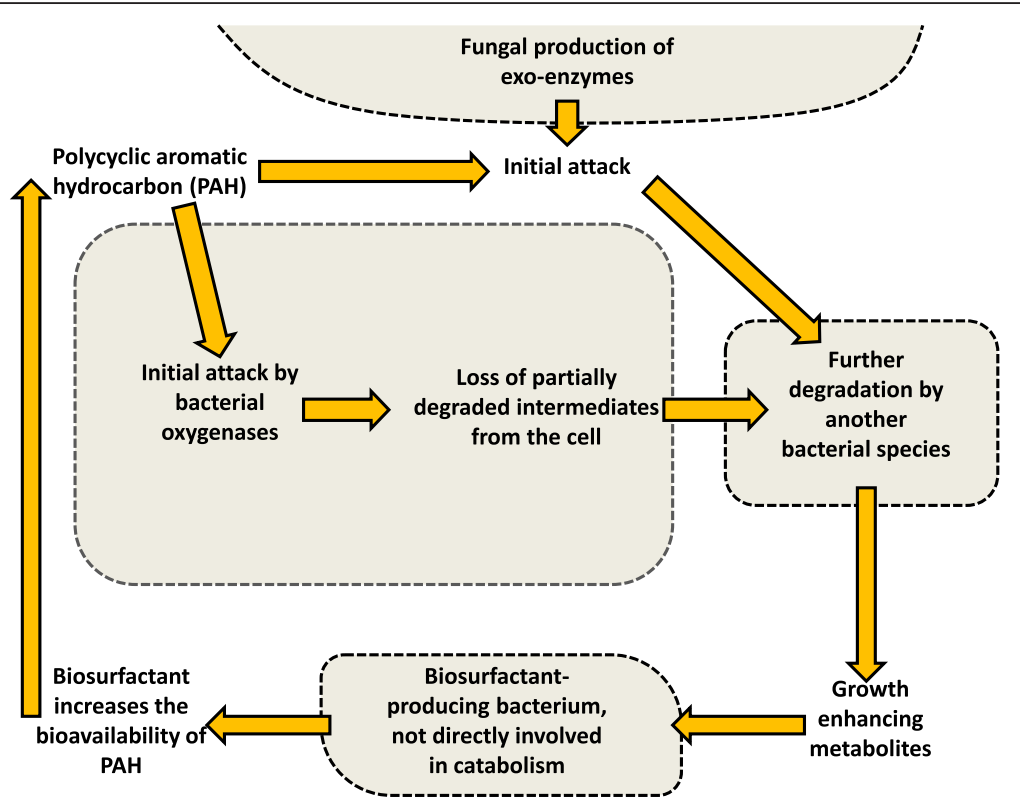

Figure 3 Schematic illustration of some of the interactions seen in a microbial consortium degrading polycyclic aromatic hydrocarbons (PAHs). Different microbial cells are represented by shaded shapes surrounded by a dashed line. Elements of these interactions have been seen in several studies (see text for details). Further complexity can be built into this simple schematic if one considers multiple PAHs invoking several pathways in one or more microbes, as well as co-metabolic degradation. 
example some PAH-degrading microbes have highaffinity uptake systems that efficiently reduce the PAH concentration close to the cell surface, thereby enhancing diffusive flux $[107,108]$. Living on the mineral surfaces to which PAHs are adsorbed is another strategy that reduces diffusion time [109] by physically reducing the distance between cells and substrate. During such interactions, the nature of the cell surface is extremely important; for example the mycolic acids of mycobacteria and related Actinobacteria enhance cell-surface hydrophobicity which serves to encourage biofilm formation and uptake of lipophilic compounds into the cell [110]. The production of extracellular polymeric substances (EPS) has also been shown to be an important mechanism in allowing attachment of Pseudomonas putida to solid PAHs [111]. Vaysse et al. [112] showed that Marinobacter hydrocarbonoclasticus exhibited a major change in the proteome of cells freshly detached from hexadecane compared with those attached to hexadecane. Their mobilization may be fuelled by intracellular wax esters accumulated while growing as a biofilm on hexadecane, and the dispersed cells demonstrated a high capacity to reattach to the $n$-alkane [112]. Thus, the ability to readily attach to hydrocarbons and then move to a new patch appears to be essential for many hydrocarbon-degrading bacteria. During this process the hydrocarbon surface will be modified by excreted microbial products, and would thus be expected to lead to colonization by a succession of different microbes, however we are not aware of any studies exploring this in detail. Wouters et al. [113] used differential fluorescence staining to analyse a model, threespecies community on the surface of PAH crystals, which looks like a promising tool to investigate their interactions and succession on the hydrocarbon surface.

Another mechanism for increasing the bioavaliabilty of these compounds is the production of biosurfactants (biological surface-active agents that have both hydrophilic and hydrophobic moieties). Some biosurfactants are known to inhibit certain microbes, while at the same time benefiting others by increasing the bioavailability of hydrophobic compounds that can serve as a carbon and energy source, thus acting as "common goods" [79]. Numerous studies have shown that production of biosurfactants, by either degrading or non-degrading microbes, is essential in enhancing the bioavailability of poorly soluble and adsorbed hydrocarbons [114,115]. Lowmolecular-weight biosurfactant molecules are mostly glycolipids, including rhamnolipid, trehalose lipids and sophorolipids, or lipopeptides such as surfactin, gramicidin S, and polymyxin [114,115]. High molecular weight EPS can also act as a biosurfactant, and represents a heterogeneous range of polymers composed of polysaccharides, proteins, lipopolysaccharides, lipoproteins or complex mixtures of these biopolymers [114,115]. Biosurfactants preferentially partition at the interface between polar and apolar molecules (e.g. hydrocarbons and water), producing micro-emulsions which in many cases enhance bioavailability and desorption of the hydrocarbon [115].

McKew et al. [30] demonstrated that the addition of Alcanivorax borkumensis to seawater microcosms containing crude oil, increased PAH-degradation rates despite the fact that $A$. borkumensis does not mineralise PAHs. A. borkumensis is known to produce biosurfactants, which enhance uptake of alkanes, its main source of carbon and energy [38]. It is probable that such biosurfactants produced by $A$. borkumensis fortuitously increase the availability of PAHs thereby enhancing their biodegradation by other microbes in the seawater [30]. The release of such "common goods" may benefit $A$. borkumensis by reducing the concentration of stressinducing PAHs, however those $\mathrm{PAH}$-degraders will be competing for nitrogen and phosphorous that are commonly limiting nutrients in petroleum-contaminated environments. Furthermore, the biosurfactants may benefit other alkane degraders competing directly with $A$. borkumensis for alkanes. Rhodanobacter strain BPC1 from an eight-strain consortium degrading benzo[a]pyrene in a mixture of diesel fuel components, was found to be the pivotal organism in making benzo[a]pyrene $\sim 500$ times more soluble, thus enhancing its degradation [116]. Strain $\mathrm{BPC} 1$ was unable to grow on the mixture, but grew in the presence of the other microbes, indicating that it was probably utilizing metabolites produced by other consortium members [116]. Similarly, the addition to seawater of EPS from Rhodococcus rhodochrous. S-2, that serves to protect this strain from aromatic-hydrocarbon-induced stress, enhanced crude oil degradation and stimulated the growth of Alcanivorax and especially Cycloclasticus spp. [117]. Although Cycloclasticus spp. grow in pure culture, they are frequently difficult to maintain, which together with the above observations [30,117], suggests that in nature they may typically take advantage of biosurfactants produced by other microbes.

Biosurfactants may also serve an antagonistic role they are after all important virulence factors in many pathogens - and their effects will be dose- and speciesdependent. Rhamnolipid generally enhances hydrocarbon bioavailability and degradation [30,118], but Shin et al. [119] reported that it inhibited degradation of phenanthrene by a two-species consortium of Sphingomonas and Paenibacillus sp., even though in pure culture the rhamnolipid inhibited only Sphingomonas sp. It was therefore suggested that the increased stress caused by the solubilized phenanthrene, or the rhamnolipid in the presence of solubilized phenanthrene, was responsible for inhibition of Paenibacillus sp. It is also important to consider the 
potential synergistic role of multiple biosurfactants. Rambeloarisoa et al. [120] studied an eight-strain microbial consortium from the French coast, and found that biosurfactants produced by a pure strain did not emulsify crude oil, whereas those produced by the whole bacterial community did emulsify oil and led to rapid hydrocarbon degradation [120]. The extent to which such multi-species synthesis of biosurfactants may be coordinated remains to be discovered. Microbial, petroleum and clay interactions are important but very poorly understood. Chaerun et al. [121], for example, showed that montmorillonite and kaolinite enhanced growth on heavy oil, acting as supports for microbes producing EPS, as well as buffering the $\mathrm{pH}$. Degradation of adsorbed PAHs involves specific adaptations that are still not well understood, and some microbes specialise in accessing and degrading adsorbed PAHs [107]. Vacca et al. [122] showed that none of the 25 soil strains isolated with non-sorbed phenanthrene could mineralise humic-acid sorbed phenanthrene (HASP), whereas all three strains that were enriched on HASP were proficient at mineralising it, clearly indicating that different capacities are needed for the biodegradation of adsorbed PAHs.

\section{Microbial interactions during anaerobic degradation of hydrocarbons}

Biodegradation of hydrocarbons in anoxic marine sediments is slower than in oxic zones, and it is generally assumed that the primary mechanism of hydrocarbon degradation even in marine sediments is aerobic respiration [123]. Despite the absence of oxygen to activate hydrocarbons, other mechanisms [124] can lead to the initiation of their degradation by a wide range of anaerobic species utilising diverse terminal electron acceptors [124]. In the environment, anaerobic hydrocarbon biodegradation is most likely to involve syntrophic consortia. Conversion of $n$ hexadecane to methane in an anaerobic enrichment culture was shown to involve a consortium of microorganisms, which on the basis of phylogenetic affiliation had the following putative phenotypes: syntrophs belonging to the Syntrophaceae (called Syntrophus but probably Smithella [125]) that convert $n$-hexadecane to acetate, hydrogen and $\mathrm{CO}_{2}$; methanogens that convert acetate to methane and $\mathrm{CO}_{2}$; other methanogens that convert hydrogen and $\mathrm{CO}_{2}$ to methane; and a Desulfovibrio sp. that may couple hydrogen and $\mathrm{CO}_{2}$ consumption with sulfate reduction [126]. However, a fermentative, syntrophic role for Desulfovibrio sp. must be considered given its metabolic flexibility [127]. A methanogenic consortium with a remarkably similar structure was also found to degrade toluene [128]. Such microbial teamwork is common in the anaerobic mineralisation of structurally complex compounds. The syntrophic association is important because the methanogens lower the concentrations of hydrogen and acetate, which makes the breakdown of the alkane energetically favourable. It will be important to elucidate the precise nature of such interactions involved in the thermodynamically challenging anaerobic degradation of hydrocarbons, particularly identifying the microbes responsible for the initial activation and their mode of action [129]. The extremely high level of enrichment in methanogenic hydrocarbon-degrading consortia provides strong evidence $[125,126]$ that Smithella spp. play this role. Better means of identifying and tracking intermediate metabolites will also be essential to better understanding the mechanism of these closely coupled syntrophic consortia.

It is important to consider that in many environments a gradient of oxygen concentrations can be found, with consequent microbial adaptations to a microaerobic lifestyle. Benzene degradation, for example, has been shown to occur at $0.05 \mathrm{mg} \mathrm{l}^{-1}$ of oxygen [130]. Moreover, aerobes and anaerobes can co-exist in chemostats [131,132]. For example, the strict aerobe, Comamonas testosteroni, and strict anaerobe, Methanosarcina barkeri, grew together, with the aerobe consuming the oxygen and maintaining it at a subinhibitory concentration for the methanogen [132]. Similar mixed cultures were detected in a benzene-contaminated aquifer [133], but the nature of the interaction in situ remains to be elucidated. Diurnal fluctuation in photosynthetically derived oxygen is an important consideration in coastal biofilms, and sequential aerobic-anaerobic hydrocarbon degradation may be an important mechanism. For instance, Chayabutra and Ju [134] investigated the sequential degradation of $n$-hexadecane by Pseudomonas aeruginosa using aerobic resting cells in the initial aerobic mineralization and inducing nitrate-reducing conditions for subsequent anaerobic degradation of oxidized metabolites. Providing oxic-anoxic transitions for the treatment of oily sludge proved as effective as oxic conditions alone in the degradation of PAHs by a microbial community dominated by Pseudomonas spp. [135]. Rocchetti et al. [136] also compared microbial degradation of hydrocarbons under both oxic and anoxic conditions in addition to sequential oxic-anoxic treatment in microcosms containing contaminated sediments. They reported that hydrocarbon degradation was significantly enhanced via sequential anaerobic-aerobic degradation involving sulfate-reducing bacteria in the anaerobic step, compared to degradation under either aerobic or anaerobic conditions. A more thorough review of this topic that describes other outcomes as well as the effect of the starting conditions (oxic or anoxic) is provided by Cravo-Laureau et al. [137].

\section{Phototroph-heterotroph interactions}

Marine phototrophs (primarily eukaryotic microalgae and cyanobacteria) contribute half the Earth's primary production and half of the oxygen liberated to the atmosphere [138]. However, they do not exist in isolation, and their phycosphere (loosely defined as the zone 
around algal cells in which bacteria feed on algal products) constitutes an important habitat that is colonised by an abundant and diverse community of heterotrophic bacteria [72,139]. Bacteria are also found living inside microalgal cells - many with unknown function [140]. The composition of free-living marine microbial communities is frequently very different from those attached to microalgae [141], with certain groups often preferring the attached lifestyle [142] and showing higher levels of activity [143]. Moreover, different species of microalgae host distinct bacterial communities that change with time and environmental conditions [72,144]. However, there is likely to be a large spectrum of bacterial heterotroph-phototroph specificity [145], and certainly many attached bacteria can also live in the absence of a microalgal or cyanobacterial host [146]. While antagonistic interactions occur between marine phototrophs and their attached microbiota [147,148], mutualistic interactions are common, with the host supplying carbon and energy sources [149], as well as potential protection from desiccation and grazing via their EPS; while the bacteria have been shown to provide iron [150], haem [151], vitamin B12 [152], to consume oxygen [153] and provide protection from reactive oxygen species [154]. Symbiotic cyanobacteria supply fixed nitrogen to diatoms [155] and other algae and protists [156], and heterotrophic $\mathrm{N}_{2}$-fixing bacteria may also be important in interactions with microalgae, as evidenced by the abundance of alphaproteobacterial diazotrophs in seawater size fractions of $>10$ $\mu \mathrm{m}$ [157]. Attached bacteria can affect microalgal morphogenesis [158], the composition of their EPS [159] and enhance aggregate formation [160]. Indeed, many microalgae function less efficiently or do not even grow as axenic cultures [161]. Bruckner et al. [162] showed that a complex network of chemical cues, including amino acids and EPS, may be involved in regulation of diatombacteria biofilms. The variety of metabolites released from both microalgal and bacterial cells is immense [163], and dissecting out those that are important or essential for nurturing specific or general interactions is a major task for the marine biochemist.

Such heterotroph-phototroph interactions are of direct relevance to hydrocarbon degradation, not least because oil has most environmental impact where it floats on the sea surface and especially intertidal areas where microalgal biofilms are usually dominant. Although the watersoluble fraction from oil was shown to reduce the abundance of marine phytoplankton (primarily Prochlorococcus), the effect on coastal planktonic diatoms was stimulatory for small $(<20 \mu \mathrm{m})$ species and either inhibitory or stimulatory depending on the concentration for larger diatoms [164]. Many marine phototrophs can withstand high concentrations of crude oil, and some cyanobacteria appear to accumulate hydrocarbons without degrading them in inter-thylakoid spaces [165]. Coastal biofilms are particularly resistant to oil pollution, which can even result in enhanced photosynthetic activity [166]. The cyanobacterial genus, Oscillatoria, is particularly common in oil-polluted mats [167-169]. Diatoms too are often abundant in diverse oil-polluted sediments, including a chronically oil-polluted lagoon in which diatom chloroplast $16 \mathrm{~S}$ rRNA gene sequences constitute up to $21 \%$ of the sequences from the surface sediment [170].

Although there are many reports of hydrocarbon degradation directly by microalgal species, primarily chlorophytes and diatoms (as summarised by Prince [17]), but also cyanobacteria, it is questionable whether microalgae would be competitive with specialist aerobic heterotrophs, and they are probably involved only in partial oxidation [171-174]. For example, Todd et al. [174] showed that the chlorophyte, Chlorella vulgaris slowly metabolized naphthalene to 1- naphthol. However, other evidence implicates photo-(mixo)trophs in complete hydrocarbon oxidation. For example, fatty acid analysis of cyanobacteria grown with and without hydrocarbons, suggests that they are incorporated into biomass [175]. Also, Lei et al. [176] reported that six strains from diverse microalgal genera, including Chlamydomonas, Chlorella, Scenedesmus, Selenastrum and Synechocystis, could degrade 34 to $100 \%$ of the supplied pyrene in 7 days.

It is difficult to obtain axenic cultures of microalgae, and so in some reports of more complete and rapid hydrocarbon degradation by phototrophs the degradation could have been performed wholly or partly by associated microbes [177]. For example, the medium used to check for the absence of heterotrophic bacteria in cyanobacterial cultures that degraded $50 \%$ of hexadecane and up to $90 \%$ of PAHs in 10 days [178] contained peptone-glucose that would not have allowed Alcanivorax spp. to grow, and so they would evade detection. De Oteyza et al. [179] have shown that while cyanobacterial filaments surround oil droplets, biodegradation was most likely due to associated heterotrophic bacteria. Cohen [168] found rapid degradation in cyanobacterial mats, whereas pure cyanobacterial cultures could not degrade hydrocarbons. Therefore, while cyanobacteria-dominated mats can degrade hydrocarbons, it is the heterotrophic bacteria that are mainly responsible for the degradation $[166,168,177,180-182]$. However, it is important to determine the extent to which microalgal biodegradation of hydrocarbons and their metabolites $[173,183]$ is relevant in the marine environment.

Phototroph-heterotroph interactions are very important to hydrocarbon biodegradation. Many algae produce hydrocarbons $[184,185]$, and nearly all produce the volatile hydrocarbon, isoprene [186,187], which could serve to sustain hydrocarbon-degrading communities in the absence of an oil spill [188], and may explain why hydrocarbon-degrading bacteria, such as Alcanivorax spp., 
are often associated with micro-[189] and macro-[190] algae. PAHs adsorb to the cell surface of marine microalgae at relatively high concentrations [191], and have been shown to be transported by phytoplankton cells from the surface layers of the Southern Baltic to the sea floor [192]. Thus, exogenous hydrocarbons may also support hydrocarbonoclastic bacteria attached to algae. Other bacterial genera that have many species with the capacity for hydrocarbon degradation, such as Marinobacter and Roseobacter, are also commonly associated with algae $[144,160,168,189,193]$; however both are nutritionally versatile and so could use diverse sources of carbon and energy supplied by their hosts. Gutierrez et al. [59] isolated a new species of specialist PAH degrader, named Porticoccus hydrocarbonoclasticus, from the marine dinoflagellate Lingulodinium polyedrum, and also used quantitative PCR to show that it was associated with other phytoplankton.

Figure 4 shows some of the means by which algae and associated bacteria collectively interact, as discussed previously. These associations may be enhanced by the presence of hydrocarbons; for example oxygen liberated by photosynthesis is likely to be very important in activating hydrocarbons and serving as an electron acceptor in aerobic respiration $[75,168,179,194]$. In turn, the locally increased concentration of $\mathrm{CO}_{2}$ produced by the heterotrophs, will generally allow enhanced photosynthesis. Abed [194] studied the interactions between cultivated cyanobacteria and aerobic heterotrophic bacteria in the degradation of hydrocarbons, showing an increase in growth of the bacteria and enhanced hydrocarbon degradation in the presence of cyanobacterial organic exudates. Similarly, extracts from a chlorophyte enhanced benzo[a]pyrene degradation by a Mycobacterium sp. and Sphingomonas sp. [195]. The consortium constructed by Tang et al. [196] consisted of an alga, Scenedesmus obliquus GH2, that could not degrade petroleum hydrocarbons but promoted the degradation of both aliphatic and aromatic hydrocarbons (especially HMW PAHs) by the added bacterial members of the consortium. In this interesting study it was also observed that when a unialgal, but non-axenic, culture of Scenedesmus obliquus GH2 was added to the consortium, degradation was inhibited, implying that unidentified non-hydrocarbon-degrading bacteria associated with the alga outcompeted the added oil-degrading bacteria.

The organic compounds produced by algae may influence hydrocarbon degradation in different ways. Algal EPS could serve to emulsify hydrocarbons as suggested by Cohen [168]. Additionally, EPS together with excreted amino acids and sugars provide a source of carbon and energy for associated bacteria (as well as the microbial community beyond the phycosphere) [197]. It is not known what effect algal dissolved organic matter (DOM) might have on hydrocarbon biodegradation, but in other environments the addition of organic compounds led to both increased and decreased hydrocarbon consumption [198200]. Such simple organic compounds significantly enhance microbial populations, a proportion of which may also have the capacity to degrade hydrocarbons. (This is the explanation often given for the success of phytoremediation of polluted land, where plant-root exudates stimulate microbial growth). Alternatively, the stimulated populations may out-compete hydrocarbon-degrading bacteria, especially obligate hydrocarbonoclastic species. In summary, we do not yet have a mechanistic explanation for the above [194-196] observations of stimulation of hydrocarbon degradation by algal exudates. The possibility should also be considered that algae produce secondary metabolites to specifically nurture hydrocarbonoclastic

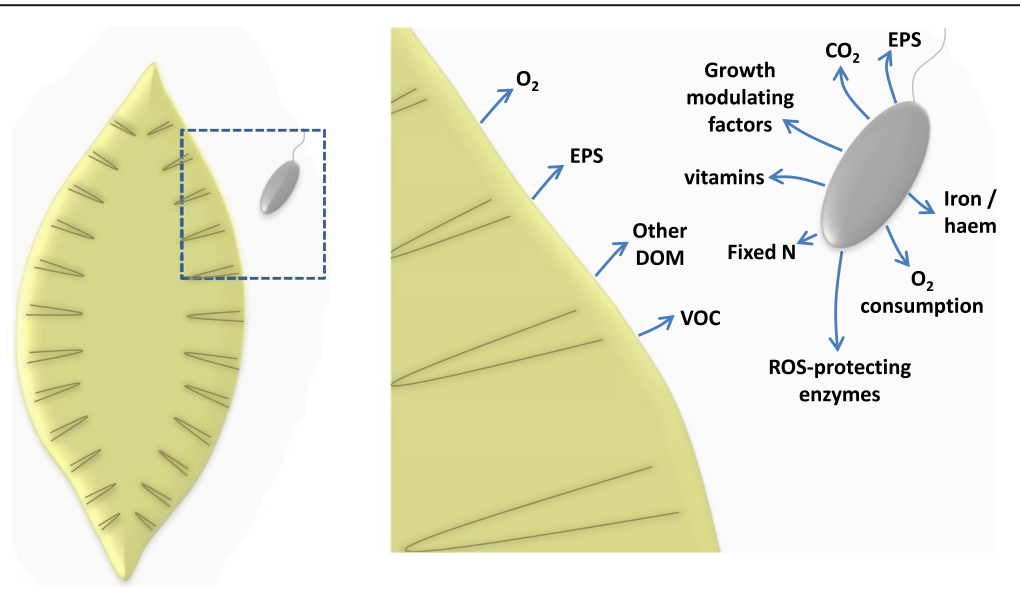

Figure 4 Schematic illustration of the transfer of metabolites between a photoautotrophic alga (gold) and an organoheterotrophic bacterium (dark grey) embedded in algal extracellular polymeric substances (light grey). The right-hand diagram is an expansion of the area in the box. EPS = extracellular polymeric substances, $D O M=$ dissolved organic matter, $V O C=$ volatile organic compounds, $R O S=$ reactive oxygen species. 
bacteria, as removal of stressful hydrocarbons would benefit the host.

Hydrocarbon-degrading bacteria could supply the algae with the benefits outlined in Figure 4. Alcanivorax and Marinobacter spp., for example, are well adapted to sequestering iron $[40,150]$. Most importantly, hydrocarbonoclastic bacteria will decrease the concentration and toxicity of hydrocarbons in the immediate vicinity of algal cells. There are several studies that demonstrate the benefit of such a co-culture; for example Abed [194] showed that the cyanobacterium Synechocystis sp. grew best in the presence of aerobic hydrocarbon-degrading bacteria and hexadecane. Alcanivorax spp., which have been shown to inhabit the phycosphere of algae such as the dinoflagellate Gymnodinium catenatum [189], can reduce the lag phase and enhance the maximum chlorophyll fluorescence of the cyanobacterium Prochlorococcus by means of diffusible molecules [201].

Nitrogen often becomes limiting in petroleumcontaminated environments [202], yet there are few studies on the impact of hydrocarbons on fixation of atmospheric nitrogen and in turn how this may influence biodegradation. Oil had little effect on nitrogen fixation in Arctic marine sediments [203] and marine-sediment microcosms [204], and had variable impact in salt-marsh sediments [205]. However, nitrogen limitation in other oil-polluted habitats can be overcome by dinitrogen fixation [206,207]. Musat et al. [204] demonstrated that cyanobacteria were the most active dinitrogen fixers in nitrogen-limited pristine and oil-polluted marine sediments reconstructed in aquaria, by combining acetylene-reduction assays with light-dark incubations and sequence analysis of expressed nif $\mathrm{H}$ genes. The capacity to fix atmospheric nitrogen and solubilise phosphate should be advantageous for microbes that rely largely on a diet of hydrocarbons. Also, the ability to scavenge iron, a major component of hydrocarbonactivating oxygenases, would be important in oligotrophic environments. There was little data suggesting that these capabilities may be widespread in hydrocarbon degraders until two recent studies showed that many hydrocarbondegrading bacterial isolates potentially [208] or actually [190] fix nitrogen, and $84 \%$ of isolates produced siderophores to access iron and 51\% solubilised phosphate [208].

\section{Grazers and viruses}

In order to better understand natural attenuation and determine the potential for bioaugmentation of oilcontaminated marine environments, it is essential to understand the effect of oil on grazers [27]. Grazing organisms play a role in the transfer of hydrocarbons or their metabolites to higher trophic levels, and also affect degradation rates, both positively and negatively [209]. It is pertinent to ask whether hydrocarbonoclastic bacteria forming biofilms on oil droplets are grazed by protozoa (e.g. ciliates and flagellates) or meiofauna (e.g. nematodes, copepods and ostracods) to the same extent as other bacteria. The grazer would have to avoid coingestion of oil or subsequently tolerate or expel it. Stoeck and Edgcomb [209], summarising the rather scant literature on this topic, state that defence mechanisms include release of protective mucous and complexation of hydrocarbons with lipids. Many grazers are resistant to crude-oil components, for example Gertler et al. [210] found an abundant, fluctuating protozoal community alongside an abundant, inversely fluctuating and active hydrocarbon-degrading bacterial community in a marine mesocosm. The main protozoal species changed over time, with selection in the oiled mesocosm of Scuticocilitia spp. initially and Euplotes spp. later, both of which had been found by other researchers in polluted environments [210]. Also, Dalby et al. [211] concluded that cosmopolitan generalist protozoa could effectively graze bacteria in crude-oil amended microcosms. In the presence of oil, the flagellate, Paraphysomonas foraminifera, became dominant (48-82\% of $18 \mathrm{~S}$ rRNA phylotypes), keeping the bacterial population below $10^{7}$ cells $\mathrm{ml}^{-1}$.

Grazing frequently leads to enhanced rates of organic matter mineralisation by releasing nutrients and/or maintaining heterotrophic populations in exponential growth phase [209]. However, there are few studies investigating the effects on hydrocarbon mineralisation, and the outcomes are sometimes conflicting, perhaps as a consequence of environmental differences or technical approaches. Using eukaryote inhibitors, Tso and Taghon [212] showed that grazing had a beneficial effect on naphthalene degradation in estuarine sediments, possibly because the protozoa selectively grazed those bacteria that were not attached to naphthalene, thus allowing attached naphthalene-degrading bacteria to flourish by reducing competition for nutrients and other resources. Mattison and Harayama [213] reported a four-fold increase in toluene mineralization by a Pseudomonas sp. in the presence of the bacterivorous flagellate Heteromita globosa than in its absence, though Pseudomonas numbers reduced to $60 \%$ of the original biomass in the presence of the flagellate. In this case it was suggested that, in addition to selectively grazing the less-active bacteria, $H$. globosa enhanced naphthalene degradation by excreting growth-stimulating metabolites or ammonium and phosphate. Rogerson and Berger [214] proposed that stimulation of crude-oil degradation by Colpidium colpoda may additionally have been due to increasing oxygen flow caused by the swimming action of the ciliate and/or production of oil-emulsifying mucus that may have enhanced hydrocarbon bioavailability. Stoeck and Edgcomb [209] provide examples of other indirect benefits of protozoa to oil biodegradation. In contrast, 
Näslund et al. [215] found that meiofaunal grazers reduced naphthalene degradation in marine sediments. By reducing the number of larger grazers, oil pollution can result in microalgal blooms [216,217]. Although the benefits of phototrophs have been outlined earlier, such a bloom may be disadvantageous because of algal competition for nutrients with hydrocarbon-degrading bacteria. More systematic studies investigating the role of different types of grazers under defined scenarios with varying levels of complexity are required to provide a clearer understanding of the nature of the interactions involved and the impact of grazers on hydrocarbon degradation.

Bacteriovorax spp. are obligate predatory bacteria that prey on other bacteria, but information regarding their potential role in oil-degrading communities is limited and conflicting. During hydrocarbon-degradation mesocosm experiments, Bacteriovorax were detected in microbial communities between days 21 and 35 [218] and days 21 and 28 [210]. However, in a similar experiment Bacteriovorax represented $11 \%$ of the bacterial community at day 0, but by day 15 none were detected [219].

Bacteriophages might also affect microbial oil degradation either positively or negatively. Pollutants can induce prophage $[27,220]$, and the resultant bacteriophageinduced lysis of bacterial cells, unlike grazing, releases all cellular components back into the marine environment for reuse by other microbes. Such a phage-driven microbialloop was implicated in enhancing total organic carbon removal in reactors treating oil-contaminated waters [221]. Rosenberg et al. [221] found extremely high densities of bacteria and phages in these reactors, and they isolated phages, including one that infected a strain of Marinobacter cultured from the same location. Using the GeoChipbased high-throughput microarray, Lu et al. [222] observed significantly higher numbers of bacteriophage replication genes in the Deepwater Horizon deep-sea oil plume samples than in non-plume control samples collected at the same depth. Because previous studies had reported a significant increase in biomass in the plume samples [223], it was surmised that the bacteriophages provided a constant supply of nutrients needed for bacterial hydrocarbon degradation through phage-mediated biomass turnover. Furthermore, phages, together with various mobile genetic elements, are important in dissemination of valuable genetic material, including hydrocarbon-degradation genes and in the generation of new catabolic pathways via lateral gene transfer $[224,225]$.

\section{A brief overview of microbial interactions with macrofauna and plants}

There exists substantial evidence that bioturbation by larger fauna has a significant impact on the degradation of petroleum hydrocarbons in oil-contaminated sediments. By selective-removal experiments, Cuny et al. [226] found that the marine polychaete, Nereis diversicolor, increased the abundance of bacteria known to play important roles in aerobic hydrocarbon degradation. It was suggested that digestive solubilizers produced by the polychaete via feeding might have enhanced the bioavailability of the hydrocarbons and/or burrowing activities enhanced oxygen transfer to hydrocarbon-degrading bacteria. Gilbert et al. [227] had demonstrated previously that the digestive process of the polychaete Nereis virens altered the composition and reduced the concentration of ingested aliphatic hydrocarbons. It was therefore surmised that surfactant production in the gut of the worm led to these changes in the hydrocarbons. In addition to aerating deeper sediments, burrowing animals may transport pollutants or degrading bacteria deeper into sediments or return buried pollutants back to the surface [228,229].

Plant roots oxygenate their rhizosphere and provide sugars and other compounds that stimulate microbial activity; and ultimately their major polymers, such as lignin, upon entering the soil will be attacked by a suite of (fungal) extracellular enzymes, which will initiate fungal degradation of PAHs. Phytoremediation, which exploits these features, has been employed in terrestrial soils, but only trials have been carried out in coastal zones [230]. For example, Lin and Mendelssohn [231] investigated both tolerance limit to crude oil and phytoremediation potentials of the salt-marsh grass Spartina patens. It could survive at concentrations up to $320 \mathrm{mg}$ oil g $\mathrm{g}^{-1}$ dry sediment, and at oil doses of between 40 and $160 \mathrm{mg} \mathrm{g}^{-1}$ oil degradation was significantly higher than in unplanted sediments. The rhizopheres of mangrove species were shown to harbour a variety of bacteria that both degraded oil and potentially stimulated plant growth [208]. As with algal-bacterial interactions, a more complete understanding of the molecular interactions between plants and associated bacteria and fungi will only improve the possibility of this technology being rationally applied to remove oil in the coastal zone [232].

\section{Concluding remarks and prospects for using interacting microbes for oil-spill cleanup}

There has been a lot of debate about the validity of bioaugmentation, specifically supplementing the environment with microbes to enhance biodegradation or detoxification of pollutants. Examples of success and failure abound. The key reasons for failure include: use of a single organism, focus on biodegrading strains only, microbes not adapted to the environment, inadequate dispersion/ access to the pollutant, lack of protection (e.g. from grazers), other factors limiting biodegradation (e.g. nutrients). Now, there is overwhelming evidence that using a consortium of microbes rather than a single strain greatly enhances the chances of successful bioaugmentation. 
A well designed microbial consortium will have complementary catabolic pathways, as well as the potential to disperse and make the hydrocarbons readily bioavailable. Gallego et al. [233], for example, demonstrated the vastly superior efficacy of a designed four-species consortium over individual species in the bioremediation of oiltank sludge. A six-species manufactured consortium, including a fungus, Fusarium sp., mineralised $78 \%$ of the PAHs from soil in 70 days, compared with negligible mineralization in an uninoculated control, and much lower degradation with single-species inocula [234]. Successful bioaugmentation is also a function of the competition between the introduced microorganisms and the autochthonous microbial community, and the study of this biotic pressure requires more attention.

Despite the improved biodegradation of hydrocarbons in bacterial co-cultures with microalgae, there have been few attempts to exploit this in the remediation of petroleum contamination. Munoz and Guieysse [235] describe ex-situ bioremediation using photobioreactors, but for marine pollution an in-situ approach is preferred owing to the large volume of polluted material. The critical phase of crude-oil contamination of the shoreline is the first few days. If the oil is not rapidly degraded then it will start to sink into the sediment where it can remain for decades. While it is true that hydrocarbonoclastic microbes will emerge from the native community, this process may take days. Thus, there is a role for bioaugmentation to bolster the in-situ hydrocarbon-degrading community in this crucial period. The potential to apply relevant hydrocarbonoclastic bacteria with or without associated microalgae should be investigated further.

Clearly there are many fundamental gaps in our understanding of microbial interactions; however, by a combination of reductionist experiments through to modelling the co-occurrence of microbial communities on a large scale, the field is advancing. The nature of interactions can be captured by single-cell and in-situmetabolism imaging techniques such as Raman-FISH [236] and Nano-SIMS [237], as well as co-localisation studies using Magneto-FISH [238]. The requisite tools are constantly being developed, such that we can characterise and analyse in more depth the function of diverse components of DOM or the epimetabolome, as well as the volatile organic compounds, including the allimportant signalling molecules. It is essential to make greater sense of metabolomics and protein and gene expression analyses in microbial consortia via the tools of systems biology [86,239]. A better understanding of microbial community metabolic networks will arise from recreating natural consortia in which modifications can be made a gene at a time. The result will be a clearer picture of microbial interactions and thus the functioning of global biogeochemical cycles, with potential practical offshoots, not least a more rational approach to the remediation of marine pollution.

\section{Competing interests}

The authors declare that they have no competing interests.

\section{Authors' contributions}

TJM conceived the review and wrote the first draft. All authors contributed to the writing and read and approved the final manuscript.

\section{Acknowledgements}

TJM is grateful to members of the European Community Sixth Framework project FACEiT (project $n^{\circ} 018391$ ) for many interesting discussions. GOS and BDF would like to acknowledge the Petroleum Technology Development Fund (PTDF), Nigeria, and NERC, UK, respectively for funding their PhD Programmes. Particular thanks go to Professors Ken Timmis and Graham Underwood for inspirational and entertaining discussions about microbial interactions.

Invited review for Aquatic Biosystems.

Received: 6 February 2012 Accepted: 25 April 2012

Published: 16 May 2012

\section{References}

1. Halpern BS, Walbridge S, Selkoe KA, Kappel CV, Micheli F, D'agrosa C, Bruno JF, Casey KS, Ebert C, Fox HE, Fujita R, Heinemann D, Lenihan HS, Madin EM, Perry MT, Selig ER, Spalding M, Steneck R, Watson R: A global map of human impact on marine ecosystems. Science 2008, 319:948-952.

2. National Research Council (NRC): Oil in the Sea III: Inputs, Fates, and Effects. Washington, D.C: National Academy Press; 2003.

3. Crone TJ, Tolstoy M: Magnitude of the 2010 Gulf of Mexico oil leak. Science 2010, 330:634.

4. ITOPF: Oil Tanker Spill Statistics: 2005. London: The International Tanker Owners Pollution Federation Ltd; 2006.

5. de la Huz R, Lastra M, Junoy J, Castellanos C, Vieitez JM: Biological impacts of oil pollution and cleaning in the intertidal zone of exposed sandy beaches: Preliminary study of the "Prestige" oil spill. Estuarine Coastal Shelf Sci 2005, 65:19-29.

6. Mason C: Biology of Freshwater Pollution. Essex: Prentice Hall; 2002

7. Carls MG, Rice SD, Hose JE: Sensitivity of fish embryos to weathered crude oil: I. Low level exposure during incubation causes malformations, genetic damage, and mortality in larval Pacific herring (Clupea pallasi). Environ Toxicol Chem 1999, 18:481-493.

8. Heintz RA: Chronic exposure to polynuclear aromatic hydrocarbons in natal habitats leads to decreased equilibrium size, growth, and stability of pink salmon populations. Integr Environ Assess Manag 2007, 3:351-363.

9. Davies JM, Addy JM, Blackman RA, Blanchard JR, Ferbrache JE, Moore DC, Somerville HJ, Whitehead A, Wilkinson T: Environmental effects of the use of oil-based drilling muds in the North Sea. Mar Pollut Bull 1984, 15:363-370

10. Venosa AD, Campo P, Suidan MT: Biodegradability of lingering crude oil 19 years after the Exxon Valdez oil spill. Environ Sci Technol 2010, 44:76137621.

11. Marshall AG, Rodgers RP: Petroleomics: the next grand challenge for chemical analysis. Accounts of Chemical Research 2004, 37:53-59.

12. Harayama S, Kishira H, Kasai Y, Shutsubo K: Petroleum biodegradation in marine environments. J Mol Microbiol Biotechnol 1999, 1:63-70.

13. van Hamme JD, Singh A, Ward OP: Recent advances in petroleum microbiology. Microbiol Mol Biol Rev 2003, 67:503-549.

14. Suess E: Marine cold seeps. In Handbook of Hydrocarbon and Lipid Microbiology. Edited by Timmis KN, McGenity TJ, van der Meer JR, de Lorenzo V. Berlin Heidelberg: Springer; 2010:187-203.

15. Prince RC, Gramain A, McGenity TJ: Prokaryotic hydrocarbon degraders. In Handbook of Hydrocarbon and Lipid Microbiology. Edited by Timmis KN, McGenity TJ, van der Meer JR, de Lorenzo V. Berlin Heidelberg: Springer; 2010:1671-1692.

16. Al-Mailem DM, Sorkhoh NA, Al-Awadhi H, Eliyas M, Radwan SS: Biodegradation of crude oil and pure hydrocarbons by extreme halophilic archaea from hypersaline coasts of the Arabian Gulf. Extremophiles 2010, 14:321-328. 
17. Prince RC: Eukaryotic hydrocarbon degraders. In Handbook of Hydrocarbon and Lipid Microbiology. Edited by Timmis KN, McGenity TJ, van der Meer JR, de Lorenzo V. Berlin Heidelberg: Springer; 2010:2065-2078.

18. Pérez-Pantoja D, González B, Pieper DH: Aerobic degradation of aromatic hydrocarbons. In Handbook of Hydrocarbon and Lipid Microbiology. Edited by Timmis KN, McGenity TJ, van der Meer JR, de Lorenzo V. Berlin Heidelberg: Springer; 2010:799-837.

19. Fuchs $\mathrm{G}$, Boll M, Heider J: Microbial degradation of aromatic compounds from one strategy to four. Nat Rev Microbiol 2011, 9:803-816.

20. Rojo F: Degradation of alkanes by bacteria. Environ Microbiol 2009 11:2477-2490

21. Kanaly RA, Harayama S: Advances in the field of high-molecular-weight polycyclic aromatic hydrocarbon biodegradation by bacteria. Microb Biotechnol 2010, 3:136-164.

22. Widdel F, Grundmann O: Biochemistry of the anaerobic degradation of non-methane alkanes. In Handbook of Hydrocarbon and Lipid Microbiology. Edited by Timmis KN, McGenity TJ, van der Meer JR, de Lorenzo V. Berlin Heidelberg: Springer; 2010:909-924.

23. Tierney M, Young LY: Anaerobic degradation of aromatic hydrocarbons. In Handbook of Hydrocarbon and Lipid Microbiology. Edited by Timmis KN, McGenity TJ, van der Meer JR, de Lorenzo V. Berlin Heidelberg: Springer; 2010:925-934.

24. Vogt $\mathrm{C}$, Kleinsteuber $\mathrm{S}$, Richnow $\mathrm{H}-\mathrm{H}$ : Anaerobic benzene degradation by bacteria. Microb Biotechnol 2011, 4:710-724.

25. Zedelius J, Rabus R, Grundmann O, Werner I, Brodkorb D, Schreiber F, Ehrenreich P, Behrends A, Wilkes H, Kube M, Reinhardt R, Widdel F: Alkane degradation under anoxic conditions by a nitrate-reducing bacterium with possible involvement of the electron acceptor in substrate activation. Environmental Microbiology Reports 2011, 3:125-135.

26. Harayama S, Kasai Y, Hara A: Microbial communities in oil-contaminated seawater. Curr Opin Biotechnol 2004, 15:205-214

27. Head IM, Jones DM, Röling WFM: Marine microorganisms make a meal of oil. Nat Rev Microbiol 2006, 4:173-182.

28. Yakimov MM, Timmis KN, Golyshin PN: Obligate oil-degrading marine bacteria. Curr Opin Biotechnol 2007, 18:257-266.

29. Coulon F, McKew BA, Osborn AM, McGenity TJ, Timmis KN: Effects of temperature and biostimulation on oil-degrading microbial communities in temperate estuarine waters. Environ Microbiol 2007, 9:177-186.

30. McKew BA, Coulon F, Yakimov MM, Denaro R, Genovese M, Smith CJ, Osborn AM, Timmis KN, McGenity TJ: Efficacy of intervention strategies for bioremediation of crude oil in marine systems and effects on indigenous hydrocarbonoclastic bacteria. Environ Microbiol 2007, 9:1562-1571.

31. Teramoto M, Suzuki M, Okazaki F, Hatmanti A, Harayama S: Oceanobacterrelated bacteria are important for the degradation of petroleum aliphatic hydrocarbons in the tropical marine environment. Microbiology 2009, 155:3362-3370.

32. Kostka JE, Prakash O, Overholt WA, Green SJ, Freyer G, Canion A, Delgardio J, Norton N, Hazen TC, Huettel M: Hydrocarbon-degrading bacteria and the bacterial community response in Gulf of Mexico beach sands impacted by the Deepwater Horizon oil spill. Appl Environ Microbiol 2011, 77:79627974.

33. Teira E, Lekunberri I, Gasol JM, Nieto-Cid M, Alvarez-Salgado XA, Figueiras FG: Dynamics of the hydrocarbon-degrading Cycloclasticus bacteria during mesocosm-simulated oil spills. Environ Microbiol 2007, 9:2551-2562.

34. McKew BA, Coulon F, Osborn AM, Timmis KN, McGenity TJ: Determining the identity and roles of oil-metabolizing marine bacteria from the Thames estuary, UK. Environ Microbiol 2007, 9:165-176.

35. Cui ZS, Lai QL, Dong CM, Shao ZZ: Biodiversity of polycyclic aromatic hydrocarbon-degrading bacteria from deep sea sediments of the Middle Atlantic Ridge. Environ Microbiol 2008, 10:2138-2149.

36. Niepceron M, Portet-Koltalo F, Merlin C, Motelay-Massei A, Barray S, Bodilis J: Both Cycloclasticus spp. and Pseudomonas spp. as PAH-degrading bacteria in the Seine estuary (France). FEMS Microbiol Ecol 2010, 71:137-147.

37. Yakimov MM, Golyshin PN, Lang S, Moore ERB, Abraham WR, Lunsdorf $H$, Timmis KN: Alcanivorax borkumensis gen. nov., sp. nov., a new, hydrocarbon-degrading and surfactant-producing marine bacterium. Int J Syst Bacteriol 1998, 48:339-348.

38. Schneiker SVA, dos Santos PM, Bartels D, Bekel T, Brecht M, Buhrmester J, Chernikova TN, Denaro R, Ferrer M, Gertler C, Goesmann A, Golyshina OV Kaminski F, Khachane AN, Lang S, Linke B, McHardy AC, Meyer F, Nechitaylo T, Pühler A, Regenhardt D, Rupp O, Sabirova JS, Selbitschka W, Yakimov MM,
Timmis KN, Vorhölter FJ, Weidner S, Kaiser O, Golyshin PN: Genome sequence of the ubiquitous hydrocarbon-degrading marine bacterium Alcanivorax borkumensis. Nat Biotechnol 2006, 24:997-1004.

39. Sabirova JS, Ferrer M, Regenhardt D, Timmis KN, Golyshin PN: Proteomic insights into metabolic adaptations in Alcanivorax borkumensis induced by alkane utilization. J Bacterio/ 2006, 188:3763-3773.

40. Sabirova JS, Chernikova TN, Timmis KN, Golyshin PN: Niche-specificity factors of a marine oil-degrading bacterium Alcanivorax borkumensis SK2. FEMS Microbiol Lett 2008, 285:89-96.

41. Ron E, Rosenberg E: Acinetobacter and Alkanindiges. In Handbook of Hydrocarbon and Lipid Microbiology. Edited by Timmis KN, McGenity TJ, van der Meer JR, de Lorenzo V. Berlin Heidelberg: Springer; 2010:1800-1803.

42. van Beilen JB, Funhoff EG: Alkane hydroxylases involved in microbial alkane degradation. Appl Microbiol Biotechnol 2007, 74:13-21.

43. Throne-Holst M, Wentzel A, Ellingsen TE, Kotlar HK, Zotchev SB: Identification of novel genes involved in long-chain $n$-alkane degradation by Acinetobacter sp. strain DSM 17874. Appl Environ Microbiol 2007, 73:3327-3332.

44. Liu CL, Wang WP, Wu YH, Zhou ZW, Lai QL, Shao ZZ: Multiple alkane hydroxylase systems in a marine alkane degrader, Alcanivorax dieselolei B-5. Environ Microbiol 2011, 13:1168-1178.

45. Wasmund K, Burns KA, Kurtboke DI, Bourne DG: Novel alkane hydroxylase gene (alkB) diversity in sediments associated with hydrocarbon seeps in the Timor Sea, Australia. Appl Environ Microbiol 2009, 75:7391-7398.

46. Wang W-P, Wang L-P, Shao Z: Diversity and abundance of oil-degrading bacteria and alkane hydroxylase (alkB) genes in the subtropical seawater of Xiamen Island. Microb Ecol 2010, 60:429-439.

47. Païssé $S$, Duran R, Coulon F, Goñi-Urriza M: Are alkane hydroxylase genes (alkB) relevant to assess petroleum bioremediation processes in chronically polluted coastal sediments? Appl Microbiol Biotechnol 2011, 92:835-844.

48. Golyshin PN, Ferrer M, Chernikova TN, Golyshina OV, Yakimov MM: Oleispira. In In Handbook of Hydrocarbon and Lipid Microbiology. Edited by Timmis KN, McGenity TJ, van der Meer JR, de Lorenzo V. Berlin Heidelberg: Springer; 2010:1755-1763.

49. Teramoto $M$, Ohuchi $M$, Hatmanti A, Darmayati $Y$, Widyastuti $Y$, Harayama $S$, Fukunaga Y: Oleibacter marinus gen. nov., sp. nov., a bacterium that degrades petroleum aliphatic hydrocarbons in a tropical marine environment. Int J Syst Evol Microbiol 2011, 61:375-380.

50. Golyshin PN, Chernikova TN, Abraham WR, Lunsdorf H, Timmis KN, Yakimov MM: Oleiphilaceae fam. nov., to include Oleiphilus messinensis gen. nov., sp nov., a novel marine bacterium that obligately utilizes hydrocarbons. Int J Syst Evol Microbiol 2002, 52:901-911.

51. Lanfranconi MP, Bosch R, Nogales B: Short-term changes in the composition of active marine bacterial assemblages in response to diesel oil pollution. Microb Biotechnol 2010, 3:607-621.

52. Coulon F, Chronoupolou P-M, Fahy A, Païssé S, Goñi-Urriza MS, Peperzak L, Acuña-Alvarez L, McKew BA, Brussard C, Underwood GJC, Timmis KN, Duran R, McGenity TJ: Central role of dynamic tidal biofilms dominated by aerobic hydrocarbonoclastic bacteria and diatoms in the biodegradation of hydrocarbons in coastal mudflats. Appl Environ Microbiol 2012, 78:3638-3648.

53. Buchanan A, Gonzalez JM: Roseobacter. In Handbook of Hydrocarbon and Lipid Microbiology. Edited by Timmis KN, McGenity TJ, van der Meer JR, de Lorenzo V. Berlin Heidelberg: Springer; 2010:1336-1343.

54. Gerdes B, Brinkmeyer R, Dieckmann G, Helmke E: Influence of crude oil on changes in bacterial communities in Arctic sea-ice. FEMS Microbiol Ecol 2005, 53:129-139.

55. Yu SH, Ke L, Wong YS, Ta NFY: Degradation of polycyclic aromatic hydrocarbons by a bacterial consortium enriched from mangrove sediments. Environ Int 2005, 31:149-154

56. Duran R: Marinobacter. In Handbook of Hydrocarbon and Lipid Microbiology. Edited by Timmis KN, McGenity TJ, van der Meer JR, de Lorenzo V. Berlin Heidelberg: Springer; 2010:1725-1735.

57. Vila J, Nieto JM, Mertens J, Springael D, Grifoll M: Microbial community structure of a heavy fuel oil-degrading marine consortium: linking microbial dynamics with polycyclic aromatic hydrocarbon utilization. FEMS Microbiol Ecol 2010, 73:349-362.

58. Melcher RJ, Apitz SE, Hemmingsen BB: Impact of irradiation and polycyclic aromatic hydrocarbon spiking on microbial populations in marine sediment for future aging and biodegradability studies. App/ Environ Microbiol 2002, 68:2858-2868. 
59. Gutierrez T, Nichols PD, Whitman WB, Aitken MD: Porticoccus hydrocarbonoclasticus sp. nov., an aromatic hydrocarbon-degrading bacterium identified in laboratory cultures of marine phytoplankton. Appl Environ Microbio/ 2012, 78:628-637.

60. Gauthier E, Déziel E, Villemur R, Juteau P, Lépine F, Beaudet R: Initial characterization of new bacteria degrading high-molecular weight polycyclic aromatic hydrocarbons isolated from a 2-year enrichment in a two-liquid-phase culture system. J Appl Microbiol 2003, 94:301-311.

61. Hilyard EJ, Jones-Meehan JM, Spargo BJ, Hill RT: Enrichment, isolation and phylogenetic identification of polycyclic aromatic hydrocarbondegrading bacteria from Elizabeth River sediments. App/ Environ Microbiol 2008, 74:1176-1182.

62. Edlund A, Jansson JK: Use of bromodeoxyuridine immunocapture to identify psychrotolerant phenanthrene-degrading bacteria in phananthrene-enriched polluted Baltic Sea sediments. FEMS Microbiol Ecol 2008, 65:513-525.

63. Gutierrez T, Singleton DR, Aitken MD, Semple KT: Stable isotope probing of an algal bloom to identify uncultivated members of the Rhodobacteraceae associated with low-molecular-weight polycyclic aromatic hydrocarbon degradation. Appl Environ Microbiol 2011, 77:7856-7860.

64. Kaeberlein T, Lewis K, Epstein SS: Isolating "uncultivable" microorganisms in pure culture in a simulated natural environment. Science 2002, 296:1127-1129.

65. McGenity TJ, Gramain A: Cutivation of halophilic hydrocarbon degraders. In Handbook of Hydrocarbon and Lipid Microbiology. Edited by Timmis KN, McGenity TJ, van der Meer JR, de Lorenzo V. Berlin Heidelberg: Springer; 2010:3847-3854

66. Calvo C, Martínez-Checa F, Toledo FL, Porcel J, Quesada E: Characteristics of bioemulsifiers synthesized in crude oil media by Halomonas eurihalina and their effectiveness in the isolation of bacteria able to grow in the presence of hydrocarbons. Appl Microbiol Biotechnol 2002, 60:347-351.

67. Zubkov MV, Mary I, Woodward EMS, Warwick PE, Fuchs BM, Scanlan DJ, Burkill PH: Microbial control of phosphate in the nutrient-depleted North Atlantic subtropical gyre. Environ Microbiol 2007, 9:2079-2089.

68. Suttle CA: Marine viruses - major players in the global ecosystem. Nat Rev Microbiol 2007, 5:801-812.

69. Grossart HP: Ecological consequences of bacterioplankton lifestyles: changes in concepts are needed. Environmental Microbiology Reports 2010, 2:706-714.

70. Fuhrman JA: Microbial community structure and its functional implications. Nature 2009, 459:193-199.

71. Azam F, Malfatti F: Microbial structuring of marine ecosystems. Nat Rev Microbiol 2007, 5:782-791.

72. Grossart HP, Levold F, Allgaier M, Simon M, Brinkhoff T: Marine diatom species harbour distinct bacterial communities. Environ Microbiol 2005, 7:860-873.

73. Carman KR, Dobbs FC: Epibiotic microorganisms on copepods and other aquatic crustaceans. Microscope Research Technique 1997, 37:116-135.

74. Zinger L, Amaral-Zettler LA, Fuhrman JA, Horner-Devine MC, Huse SM, Welch DB, Martiny JB, Sogin M, Boetius A, Ramette A: Global patterns of bacterial beta-diversity in seafloor and seawater ecosystems. PLoS One 2011, 6:e24570

75. Duran R, Goñi-Urriza MS: Impact of pollution on microbial mats. In Handbook of Hydrocarbon and Lipid Microbiology. Edited by Timmis KN, McGenity TJ, van der Meer JR, de Lorenzo V. Berlin Heidelberg: Springer; 2010:2339-2348.

76. Shank EA, Kolter R: New developments in microbial interspecies signaling. Curr Opin Microbiol 2009, 12:205-214.

77. Mashburn-Warren LM, Whiteley M: Special delivery: vesicle trafficking in prokaryotes. Mol Microbiol 2006, 61:839-846.

78. Dubey GP, Ben-Yehuda S: Intercellular nanotubes mediate bacterial communication. Cell 2011, 144:590-600.

79. Diggle SP: Microbial communication and virulence: lessons from evolutionary theory. Microbiology 2010, 156:3503-3512.

80. Yakimov MM, Denaro R, Genovese M, Cappello S, D'Auria G, Chernikova TN, Timmis KN, Golyshin PN, Giuliano L: Natural microbial diversity in superficial sediments of Milazzo Harbor (Sicily) and community successions during microcosm enrichment with various hydrocarbons. Environ Microbiol 2005, 7:1426-1441

81. Kanoh K, Adachi K, Katsuta A, Shizuri Y: Structural determination and proposed biosynthesis of alcanivorone, a novel alpha-pyrone produced by Alcanivorax jadensis. Journal of Antibiotics (Tokyo) 2008, 61:70-74.
82. Hara A, Syutsubo K, Harayama S: Alcanivorax which prevails in oilcontaminated seawater exhibits broad substrate specificity for alkane degradation. Environ Microbiol 2003, 5:746-753.

83. Wang BJ, Lai QL, Cui ZS, Tan TF, Shao ZZ: A pyrene-degrading consortium from deep-sea sediment of the West Pacific and its key member Cycloclasticus sp P1. Environ Microbiol 2008, 10:1948-1963.

84. Luo YR, Tian Y, Huang X, Yan CL, Hong HS, Lin GH, Zheng TL: Analysis of community structure of a microbial consortium capable of degrading benzo[a]pyrene by DGGE. Mar Pollut Bull 2009, 58:1159-1163.

85. de Lorenzo V: Systems biology approaches to bioremediation. Curr Opin Biotechnol 2008, 19:579-89.

86. de Lorenzo V, Fraile S, Jiménez Jl: Emerging systems and synthetic biology approaches to hydrocarbon biotechnology. In Handbook of Hydrocarbon and Lipid Microbiology. Edited by Timmis KN, McGenity TJ, van der Meer JR, de Lorenzo V. Berlin Heidelberg: Springer; 2010:1411-1435.

87. Pelz O, Tesar M, Wittich RM, Moore ERB, Timmis KN, Abraham WR: Towards elucidation of microbial community metabolic pathways: unravelling the network of carbon sharing in a pollutant-degrading bacterial consortium by immunocapture and isotopic ratio mass spectrometry. Environ Microbiol 1999, 1:167-174.

88. López Z, Vila J, Ortega-Calvo JJ, Grifoll M: Simultaneous biodegradation of creosote-polycyclic aromatic hydrocarbons by a pyrene-degrading Mycobacterium. Appl Microbiol Biotechnol 2008, 78:165-172.

89. Wintermute $\mathrm{EH}$, Silver PA: Emergent cooperation in microbial metabolism. Mol Syst Biol 2010, 6:407.

90. Bobadilla Fazzini RAB, Preto MJ, Quintas ACP, Bielecka A, Timmis KN, dos Santos VAPM: Consortia modulation of the stress response: proteomic analysis of single strain versus mixed culture. Environ Microbiol 2010, $12: 2436-2449$

91. Cerniglia CE, Sutherland JB: Degradation of polycyclic aromatic hydrocarbons by fungi. In Handbook of Hydrocarbon and Lipid Microbiology. Edited by Timmis KN, McGenity TJ, van der Meer JR, de Lorenzo V. Berlin Heidelberg: Springer; 2010:2080-2110.

92. Chen SH, Aitken MD: Salicylate stimulates the degradation of high molecular weight polycyclic aromatic hydrocarbons by Pseudomonas saccharophila P15. Environ Sci Technol 1999, 33:435-439.

93. da Silva M, Esposito E, Joanna D, Canhos V, Cerniglia C: Metabolism of aromatic hydrocarbons by the filamentous fungus Cyclothyrium sp. Chemosphere 2004, 57:943-952.

94. Prenafeta-Boldú FX, Summerbell R, de Hoog GS: Fungi growing on aromatic hydrocarbons: biotechnology's unexpected encounter with biohazard? FEMS Microbiol Rev 2006, 30:109-130.

95. Harms H, Schlosser D, Wick LY: Untapped potential: exploiting fungi in bioremediation of hazardous chemicals. Nat Rev Microbiol 2011, 9:177-192.

96. Johnsen A, Wick L, Harms H: Principles of microbial PAH-degradation in soil. Environ Pollut 2005, 133:71-84.

97. Kotterman M, Vis E, Field J: Successive mineralization and detoxification of benzo[a]pyrene by the white rot fungus Bjerkandera sp. strain BOS55 and indigenous microflora. Appl Environ Microbiol 1998, 64:2853-2858.

98. Boonchan S, Britz ML, Stanley GA: Degradation and mineralization of highmolecular-weight polycyclic aromatic hydrocarbons by defined fungalbacterial cocultures. Appl Environ Microbiol 2000, 66:1007-1019.

99. Haritash AK, Kaushik CP: Biodegradation aspects of polycyclic aromatic hydrocarbons (PAHs): A review. J Hazard Mater 2009, 169:1-15.

100. Kazunga C, Aitken M: Products from the incomplete metabolism of pyrene by polycyclic aromatic hydrocarbon-degrading bacteria. Appl Environ Microbiol 2000, 66:4598-4598.

101. Allen MA, Goh F, Burns BP, Neilan BA: Bacterial, archaeal and eukaryotic diversity of smooth and pustular microbial mat communities in the hypersaline lagoon of Shark Bay. Geobiology 2009, 7:82-96.

102. Valentin L, Feijoo G, Moreira MT, Lema JM: Biodegradationof polycyclic aromatic hydrocarbon in forest and salt marsh soils by white rot fungi. IntBiodeter Biodegr 2006, 58:15-21.

103. Frey-Klett $P$, Burlinson $P$, Deveau $A$, Barret M, Tarkka M, Sarniguet $A$ : Bacterial-fungal interactions: hyphens between agricultural, clinical, environmental, and food microbiologists. Microbiol Mol Biol Rev 2011 75:583-609.

104. Furuno S, Pazolt K, Rabe C, Neu TR, Harms H, Wick LY: Fungal mycelia allow chemotactic dispersal of polycyclic aromatic hydrocarbon-degrading bacteria in water-unsaturated systems. Environ Microbio/ 2010, 12:13911398 
105. Woolgar PJ, Jones KC: Studies on the dissolution of polycyclic aromatic hydrocarbons from contaminated materials using a novel dialysis tubing experimental method. Environ Sci Technol 1999, 33:2118-2126.

106. Semple KT, Doick CJ, Wick LY, Harms H: Microbial interactions with organic contaminants in soil: Definitions, processes and measurement. Environ Pollut 2007, 150:166-176.

107. Bastiaens L, Springael D, Wattiau P, Harms H, de Wachter R, Verachtert $H$, Diels L: Isolation of adherent polycyclic aromatic hydrocarbon (PAH)degrading bacteria using PAH-sorbing carriers. Appl Environ Microbiol 2000, 66:1834-1843

108. Harms H, Smith KEC, Wick LY: Microorganism-hydrophobic compound interactions. In Handbook of Hydrocarbon and Lipid Microbiology. Edited by Timmis KN, McGenity TJ, van der Meer JR, de Lorenzo V. Berlin Heidelberg: Springer; 2010:1479-1490.

109. Guerin WF, Boyd SA: Differential bioavailability of soil-sorbed naphthalene to two bacterial species. Appl Environ Microbiol 1992, 58:1142-1152.

110. Wick LY, Wattiau $P$, Harms H: Influence of the growth substrate on the mycolic acid profiles of mycobacteria. Environ Microbiol 2002, 4:612-616.

111. Rodrigues AC, Wuertz S, Brito AG, Melo LF: Fluorene and phenanthrene uptake by Pseudomonas putida ATCC 17514: Kinetics and physiological aspects. Biotechnol Bioeng 2005, 90:281-289.

112. Vaysse PJ, Sivadon P, Goulas P, Grimaud R: Cells dispersed from Marinobacter hydrocarbonoclasticus SP17 biofilm exhibit a specific protein profile associated with a higher ability to reinitiate biofilm development at the hexadecane-water interface. Environ Microbiol 2011 13:737-746.

113. Wouters K, Maes E, Spitz J-A, Roeffaers MBJ, Wattiau P, Hofkens J, Springael $D$ : A non-invasive fluorescent staining procedure allows Confocal Laser Scanning Microscopy based imaging of Mycobacterium in multispecies biofilms colonizing and degrading Polycyclic Aromatic Hydrocarbons. J Microbiol Methods 2010, 83:317-325.

114. Pacwa-Plociniczak M, Plaza GA, Piotrowska-Seget Z, Cameotra SS: Environmental applications of biosurfactants: recent advances. Int J Mol Sci 2011, 12:633-654

115. Perfumo A, Smyth TJP, Marchant R, Banat IM: Production and roles of biosurfactants and bioemulsifiers in accessing hydrophobic substrates. In Handbook of Hydrocarbon and Lipid Microbiology. Edited by Timmis KN, McGenity TJ, van der Meer JR, de Lorenzo V. Berlin Heidelberg: Springer; 2010:1501-1512

116. Kanaly RA, Harayama S, Watanabe K: Rhodanobacter sp. strain BPC1 in a benzo[a]pyrene-mineralizing microbial consortium. Appl Environ Microbiol 2002, 68:5826-5833.

117. Iwabuchi N, Sunairi M, Urai M, Itoh C, Anzai H, Nakajima M, Harayama S: Extracellular polysaccharides of Rhodococcus rhodochrous S-2 stimulate the degradation of aromatic components in crude oil by indigenous marine bacteria. Appl Environ Microbiol 2002, 68:2337-2343.

118. Abalos A, Viñas M, Sabaté J, Manresa MA, Solanas AM: Enhanced biodegradation of Casablanca crude oil by a microbial consortium in presence of a rhamnolipid produced by Pseudomonas aeruginosa AT10. Biodegradation 2004, 15:249-260.

119. Shin KH, Ahn Y, Kim KW: Toxic effect of biosurfactant addition on the biodegradation of phenanthrene. Environ Toxicol Chem 2005, 24:2768-2774

120. Rambeloarisoa E, Rontani JF, Giusti G, Duvnjak Z, Bertrand JC: Degradation of crude oil by a mixed population of bacteria isolated from sea-surface foams. Mar Biol 1984, 83:69-81.

121. Chaerun SK, Tazaki K, Asada R, Kogure K: Interaction between clay minerals and hydrocarbon-utilizing indigenous microorganisms in high concentrations of heavy oil: implications for bioremediation. Clay Minerals 2005, 40:105-114

122. Vacca DJ, Bleam WF, Hickey WJ: Isolation of soil bacteria adapted to degrade humic acid-sorbed phenanthrene. Appl Environ Microbiol 2005, 71:3797-3805

123. Shin WS, Pardue JH, Jackson WA: Oxygen demand and sulfate reduction in petroleum hydrocarbon contaminated salt marsh soils. Water Res 2000, 34:1345-1353.

124. Widdel F, Knittel K, Galushko A: Anaerobic hydrocarbon-degrading microorganisms: an overview. In Handbook of Hydrocarbon and Lipid Microbiology. Edited by Timmis KN, McGenity TJ, van der Meer JR, de Lorenzo V. Berlin Heidelberg: Springer; 2010:1997-2021.
125. Gray ND, Sherry A, Grant RJ, Rowan AK, Hubert CRJ, Callbeck CM, Aitken CM, Jones DM, Adams JJ, Larter SR, Head IM: The quantitative significance of Syntrophaceae and syntrophic partnerships in methanogenic degradation of crude oil alkanes. Environ Microbio/ 2011, 13:2957-2975.

126. Zengler K, Richnow H, Rosselló-Mora R, Michaelis W, Widdel F: Methane formation from long-chain alkanes by anaerobic microorganisms. Nature 1999, 401:266-269

127. Walker CB, He Z, Yang ZK, Ringbauer JA Jr, He Q, Zhou J, Voordouw G, Wall JD, Arkin AP, Hazen TC, Stolyar S, Stahl DA: The electron transfer system of syntrophically grown Desulfovibrio vulgaris. J Bacteriol 2009, 191:5793-5801.

128. Ficker M, Krastel K, Orlicky S, Edwards E: Molecular characterization of a toluene-degrading methanogenic consortium. Appl Environ Microbiol 1999, 65:5576-5585.

129. Mclnerney MJ, Sieber JR, Gunsalus RP: Syntrophy in anaerobic global carbon cycles. Curr Opin Biotechnol 2009, 20:623-632

130. Yerushalmi L, Lascourreges JF, Rhofir C, Guiot SR: Detection of intermediate metabolites of benzene biodegradation under microaerophilic conditions. Biodegradation 2001, 12:379-391.

131. Wimpenny JWT, Abdollahi H: Growth of mixed cultures of Paracoccus denitrificans and Desulfovibrio desulfuricans in homogeneous and in heterogeneous culture systems. Microb Ecol 1991, 22:1-13.

132. Gerritse J, Gottschal JC: Two-membered mixed cultures of methanogenic and aerobic bacteria in $\mathrm{O}_{2}$-limited chemostats. J Gen Microbiol 1993, 139:1853-1860.

133. Aburto A, Fahy A, Coulon F, Lethbridge G, Timmis KN, Ball AS, McGenity TJ: Mixed aerobic and anaerobic microbial communities in benzenecontaminated groundwaters. J Appl Microbiol 2009, 16:317-328.

134. Chayabutra C, Ju L-K: Degradation of $n$-hexadecane and its metabolites by Pseudomonas aeruginosa under microaerobic and anaerobic denitrifying conditions. Appl Environ Microbio/ 2000, 66:493-498.

135. Vitte I, Duran R, Jézéquel R, Caumette P, Cravo-Laureau C: Effect of oxic/ anoxic switches on bacterial communities and PAH biodegradation in an oil-contaminated sludge. Environ Sci Pollut Res 2011, 18:1022-1032.

136. Rocchetti L, Beolchini F, Ciani M, Dell'Anno A: Improvement of bioremediation performance for the degradation of petroleum hydrocarbons in contaminated sediments. Appl Environm Soil Sci 2011, 2011:319657.

137. Cravo-Laureau C, Hernandez-Raquet G, Vitte I, Jézéquel R, Bellet V, Godon J$J$, Caumette $\mathrm{P}$, Balaguer $\mathrm{P}$, Duran R: Role of environmental fluctuations and microbial diversity in degradation of hydrocarbons in contaminated sludge. Res Microbiol 2011, 162:888-895.

138. Field CB, Behrenfeld MJ, Randerson JT, Falkowski P: Primary production of the biosphere: Integrating terrestrial and oceanic components. Science 1998, 281:237-240

139. Biegala IC, Kennaway G, Alverca E, Lennon JF, Vaulot D, Simon N: Identification of bacteria associated with dinoflagellates (Dinophyceae) Alexandrium spp. using tyramide signal amplification-fluorescent in situ hybridization and confocal microscopy. J Phycol 2002, 38:404-411.

140. Armbrust EV: The life of diatoms in the world's oceans. Nature 2009, 459:185-192.

141. Crump BC, Armbrust EV, Baross JA: Phylogenetic analysis of particleattached and free-living bacterial communities in the Columbia River, its estuary, and the adjacent coastal ocean. Appl Environ Microbiol 1999, 65:3192-3204

142. Cottrell M, Kirchman D: Natural assemblages of marine proteobacteria and membersof the Cytophaga-Flavobacter cluster consuming low- and high-molecular-weight dissolved organic matter. Appl Environ Microbiol 2000, 66:1692-1697.

143. Allgaier M, Riebesell U, Vogt M, Thyrhaug R, Grossart HP: Coupling of heterotrophic bacteria to phytoplankton bloom development at different $\mathrm{pCO}_{2}$ levels: a mesocosm study. Biogeosciences 2008, 5:1007-1022.

144. Jasti S, Sieracki ME, Poulton NJ, Giewat MW, Rooney-Varga JN: Phylogenetic diversity and specificity of bacteria closely associated with Alexandrium spp. and other phytoplankton. App/ Environ Microbiol 2005, 71:3483-3494.

145. Sapp M, Schwaderer AS, Wiltshire KH, Hoppe HG, Gerdts G, Wichels A: Species-specific bacterial communities in the phycosphere of microalgae? Microb Ecol 2007, 53:683-699.

146. Hube AE, Heyduck-Söller B, Fischer U: Phylogenetic classification of heterotrophic bacteria associated with filamentous marine cyanobacteria in culture. Syst Appl Microbiol 2009, 32:256-265. 
147. Cole Jj: Interactions between bacteria and algae in aquatic ecosystems. Annu Rev Ecol Evol Syst 1982, 13:291-314.

148. Rivas MO, Vargas P, Riquelme CE: Interactions of Botryococcus braunii cultures with bacterial biofilms. Microb Ecol 2010, 60:628-635.

149. Bell WH, Lang JM, Mitchell R: Selective stimulation of marine bacteria by algal extracellular products. Limnol Oceanogr 1974, 19:833-839.

150. Amin SA, Green DH, Hart MC, Küpper FC, Sunda WG, Carrano CJ: Photolysis of iron-siderophore chelates promotes bacterial-algal mutualism. Proc Natl Acad Sci U S A 2009, 106:17071-17076.

151. Hopkinson BM, Roe K, Barbeau KA: Heme uptake by Microscilla marina and evidence for heme uptake systems in the genomes of diverse marine bacteria. Appl Environ Microbiol 2008, 74:6263-6270.

152. Croft MT, Lawrence AD, Raux-Deery E, Warren MJ, Smith AG: Algae acquire vitamin B12 through a symbiotic relationship with bacteria. Nature 2005 438:90-93.

153. Mouget $J$, Dakhama A, Lavoie MC, Delanoue J: Algal growth enhancement by bacteria - is consumption of photosynthetic oxygen involved. FEMS Microbiol Ecol 1995, 18:35-43.

154. Huenken M, Harder J, Kirst GO: Epiphytic bacteria on the Antarctic ice diatom Amphiprora kufferathii Manguin cleave hydrogen peroxide produced during algal photosynthesis. Plant Biology 2008, 10:519-526.

155. Villareal TA: Laboratory culture and preliminary characterization of the nitrogen-fixing Rhizosolenia-Richelia symbiosis. Mar Ecol 1990, 11:117132

156. Kneip C, Lockhart P, Voß CMaier U-G: Nitrogen fixation in eukaryotes - new models for symbiosis. BMC Evol Biol 2007, 7:55.

157. Moisander PH, Beinart RA, Voss M, Zehr JP: Diversity and abundance of diazotrophic microorganisms in the South China Sea during intermonsoon. ISME J 2008, 2:954-967.

158. Matsuo $Y$, Imagawa $H$, Nishizawa M, Shizuri $Y$ : Isolation of an algal morphogenesis inducer from a marine bacterium. Science 2005, 307:1598.

159. Bruckner CG, Bahulikar R, Rahalkar M, Schink B, Kroth PG: Bacteria associated with benthic diatoms from Lake Constance: phylogeny and influences on diatom growth and secretion of extracellular polymeric substances. Appl Environ Microbiol 2008, 74:7740-7749.

160. Gärdes A, Iversen MH, Grossart HP, Passow U, Ullrich MS: Diatom-associated bacteria are required for aggregation of Thalassiosira weissflogii. ISME J 2011, 5:436-445.

161. Bolch CJS, Subramanian TA, Green DH: The toxic dinoflagellate Gymnodinium catenatum (dinophyceae) requires marine bacteria for growth. J Phycol 2011, 47:1009-1022.

162. Bruckner CG, Rehm C, Grossart HP, Kroth PG: Growth and release of extracellular organic compounds by benthic diatoms depend on interactions with bacteria. Environ Microbiol 2011, 13:1052-1063.

163. Kujawinski EB: The impact of microbial metabolism on marine dissolved organic matter. Annu Rev Marine Sci 2011, 3:567-599.

164. González J, Figueiras FG, Aranguren-Gassis M, Crespo BG, Fernández E, Morán XAG, Nieto-Cid M: Effect of a simulated oil spill on natural assemblages of marine phytoplankton enclosed in microcosms. Estuar Coastal Shelf Sci 2009, 83:265-276.

165. Al-Hasan RH, Khanafer M, Eliyas M, Radwan SS: Hydrocarbon accumulation by picocyanobacteria from the Arabian Gulf. J Appl Microbiol 2001, 91:533-540.

166. Benthien M, Wieland A, de Oteyza T, Grimalt J, Kühl M: Oil-contamination effects on a hypersaline microbial mat community (Camargue, France) as studied with microsensors and geochemical analysis. Ophelia 2004, 58:135-150

167. Abed RM, Al-Thukair A, de Beer D: Bacterial diversity of a cyanobacterial mat degrading petroleum compounds at elevated salinities and temperatures. FEMS Microbiol Ecol 2006, 57:290-301.

168. Cohen Y: Bioremediation of oil by marine microbial mats. Int Microbiol 2002, 5:189-193.

169. van Bleijswijk J, Muyzer G: Genetic diversity of oxygenic phototrophs in microbial mats exposed to different levels of oil pollution. Ophelia 2004, 58:157-164.

170. Païssé S, Coulon F, Goñi-Urriza M, Peperzak L, McGenity TJ, Duran R: Structure of bacterial communities along a hydrocarbon contamination gradient in a coastal sediment. FEMS Microbiol Ecol 2008, 66:295-305.

171. Cerniglia CE, Van Baalen C, Gibson DT: Metabolism of naphthalene by the cyanobacterium Oscillatoria sp., strain JCM. J Gen Microbiol 1980, 116:485-594.
172. Cerniglia CE, Gibson DT, Van Baalen C: Oxidation of naphthalene by cyanobacteria and microalgae. J Gen Microbiol 1980, 116:495-500.

173. Semple KT, Cain RB, Schmidt S: Biodegradation of aromatic compounds by microalgae. FEMS Microbiol Lett 1999, 170:291-300.

174. Todd SJ, Cain RB, Schmidt S: Biotransformation of naphthalene and diaryl ethers by green microalgae. Biodegradation 2002, 13:229-238.

175. Al-Hasan RH, Sorkhoh NA, Al Bader D, Radwan SS: Utilization of hydrocarbons by cyanobacteria from microbial mats on oily coasts of the Gulf. Appl Microbiol Biotechnol 1994, 41:615-619.

176. Lei AP, Wong YS, Tam NFY: Removal of pyrene by different microalgal species. Water Sci Technol 2002, 46:195-201.

177. Abed RMM, Köster J: The direct role of aerobic heterotrophic bacteria associated with cyanobacteria in the degradation of oil compounds. Int Biodeterior Biodegrad 2005, 55:29-37.

178. Raghukumar C, Vipparty V, David JJ, Chandramohan D: Degradation of crude oil by marine cyanobacteria. Appl Microbiol Biotechnol 2001, 57:433-436.

179. de Oteyza TG, Grimalt JO, Diestra E, Sole A, Esteve I: Changes in the composition of polar and apolar crude oil fractions under the action of Microcoleus consortia. Appl Microbiol Biotechnol 2004, 66:226-232.

180. Abed RMM, Safi NMD, Koster J, de Beer D, El-Nahhal Y, Rullkotter J, GarciaPichel F: Microbial diversity of a heavily polluted microbial mat and its community changes following degradation of petroleum compounds. Appl Environ Microbiol 2002, 68:1674-1683.

181. Sánchez O, Diestra, Esteve I, Mas J: Molecular characterization of an oildegrading cyanobacterial consortium. Microb Ecol 2005, 50:580-588.

182. Chaillan F, Gugger M, Sailot A, Coute A, Oudot J: Role of cyanobacteria in the biodegradation of crude oil by a tropical cyanobacterial mat. Chemosphere 2006, 62:1574-1582.

183. Ghasemi Y, Rasoul-Amini S, Fotooh-Abadi E: The biotransformation, biodegradation, and bioremediation of organic compounds by microalgae. J Phycol 2011, 47:969-980.

184. Chisti Y: Biodiesel from microalgae. Biotechnology Advances 2007, 25:294306

185. Schirmer A, Rude MA, Li XZ, Popova E, del Cardayre SB: Microbial biosynthesis of alkanes. Science 2010, 329:559-562.

186. Shaw SL, Gantt B, Meskhidze N: Production and emissions of marine isoprene and monoterpenes: a review. Advances in Meteorology 2010, doi:10.1155/2010/408696

187. Exton DA, Steinke M, Suggett DJ, McGenity TJ: Spatial and temporal variability of biogenic isoprene emissions from a temperate estuary. Global Biogeochem Cycles 2012,26:GB2012. In press.

188. Acuña Alvarez L, Exton DA, Timmis KN, Suggett DJ, McGenity TJ: Characterization of marine isoprene-degrading communities. Environ Microbiol 2009, 11:3280-3291.

189. Green DH, Llewellyn LE, Negri AP, Blackburn SI, Bolch CJS: Phylogenetic and functional diversity of the cultivable bacterial community associated with the paralytic shellfish poisoning dinoflagellate Gymnodinium catenatum. FEMS Microbiol Ecol 2004, 47:345-357.

190. Radwan S, Mahmoud H, Khanafer M, Al-Habib A, Al-Hasan R: Identities of epilithic hydrocarbon-utilizing diazotrophic bacteria from the Arabian Gulf coasts, and their potential for oil bioremediation without nitrogen supplementation. Microb Ecol 2010, 60:354-363.

191. Binark N, Guven KC, Gezgin T, Unlu S: Oil pollution of marine algae. Bull Environ Contam Toxicol 2000, 64:866-872.

192. Kowalewska G: Phytoplankton-the main factor responsible for transport of polynuclear aromatic hydrocarbons from water to sediments in the Southern Baltic ecosystem. ICES J Mar Sci 1999, 56:219-222.

193. Geng HF, Belas R: Molecular mechanisms underlying Roseobacterphytoplankton symbioses. Curr Opin Biotechnol 2010, 21:332-338.

194. Abed RMM: Interaction between cyanobacteria and aerobic heterotrophic bacteria in the degradation of hydrocarbons. Int Biodeterior Biodegrad 2010, 64:58-64.

195. Warshawsky D, LaDow K, Schneider J: Enhanced degradation of benzo[a] pyrene by Mycobacterium sp. in conjunction with green alga. Chemosphere 2007, 69:500-506.

196. Tang X, He LY, Tao XQ, Dang Z, Guo CL, Lu GN, Yi XY: Construction of an artificial microalgal-bacterial consortium that efficiently degrades crude oil. J Hazard Mater 2010, 181:1158-1162.

197. Hofmann T, Hanlon ARM, Taylor JD, Ball AS, Osborn AM, Underwood GJC: Dynamics and compositional changes in extracellular 
carbohydrates in estuarine sediments during degradation. Mar Ecol Prog Ser 2009, 379:45-58.

198. Carmichael LM, Pfaender FK: The effect of inorganic and organic supplements on the microbial degradation of phenanthrene and pyrene in soils. Biodegradation 1997, 8:1-13.

199. Wick LY, Pasche N, Bernasconi SM, Pelz O, Harms H: Characterization of multiple substrate utilization by anthracene-degrading Mycobacterium frederiksbergense LB501T. Appl Environ Microbiol 2003, 69:6133-6142.

200. Teng Y, Luo YM, Ping LF, Zou DX, Li ZA, Christie P: Effects of soil amendment with different carbon sources and other factors on the bioremediation of an aged PAH-contaminated soil. Biodegradation 2010, 21:167-178.

201. Sher D, Thompson JW, Kashtan N, Croal L, Chisholm CW: Response of Prochlorococcus ecotypes to co-culture with diverse marine bacteria. ISME J 2011, 5:1125-1132

202. Head IM, Swannell RP: Bioremediation of petroleum hydrocarbon contaminants in marine habitats. Curr Opin Biotechnol 1999, 10:234-239.

203. Knowles R, Wishart C: Nitrogen-fixation in Arctic marine sediments - effect of oil and hydrocarbon factions. Environ Pollut 1977, 13:133-149.

204. Musat F, Harder J, Widdel F: Study of nitrogen fixation in microbial communities of oil-contaminated marine sediment microcosms. Environ Microbiol 2006, 8:1834-1843.

205. Thomson AD, Webb KL: The effect of chronic oil pollution on salt-marsh nitrogen fixation (acetylene reduction). Estuaries 1984, 7:2-11.

206. Toccalino PL, Johnson RL, Boone DR: Nitrogen limitation and nitrogenfixation during alkane biodegradation in a sandy soil. Appl Environ Microbiol 1993, 59:2977-2983.

207. Taketani RG, dos Santos HF, van Elsas JD, Rosado AS: Characterisation of the effect of a simulated hydrocarbon spill on diazotrophs in mangrove sediment mesocosm. Antonie Van Leeuwenhoek 2009, 96:343-354.

208. do Carmo FL, dos Santos HF, Martins EF, van Elsas JD, Rosado AS, Peixoto RS: Bacterial structure and characterization of plant growth promoting and oil degrading bacteria from the rhizospheres of mangrove plants. J Microbiol 2011, 49:535-543.

209. Stoeck T, Edgcomb V: Role of protists in microbial interactions with hydrocarbons. In Handbook of Hydrocarbon and Lipid Microbiology. Edited by Timmis KN, McGenity TJ, van der Meer JR, de Lorenzo V. Berlin Heidelberg: Springer; 2010:2423-2434.

210. Gertler C, Näther DJ, Gerdts G, Malpass MC, Golyshin PN: A mesocosm study of the changes in marine flagellate and ciliate communities in a crude oil bioremediation trial. Microb Ecol 2010, 60:180-191.

211. Dalby AP, Kormas KA, Christaki U, Karayanni H: Cosmopolitan heterotrophic microeukaryotes are active bacterial grazers in experimental oil-polluted systems. Environ Microbiol 2008, 10:47-56.

212. Tso SF, Taghon GL: Protozoan grazing increases mineralization of naphthalene in marine sediment. Microb Ecol 2006, 51:460-469.

213. Mattison RG, Harayama S: The predatory soil flagellate Heteromita globosa stimulates toluene biodegradation by a Pseudomonas sp. FEMS Microbiol Lett 2001, 194:39-45.

214. Rogerson A, Berger J: Enhancement of the microbial degradation of crude petroleum by the ciliate Colpidium colpoda. J Gen Appl Microbiol 1983, 29:41-50

215. Näslund J, Nascimento FJA, Gunnarsson JS: Meiofauna reduces bacterial mineralization of naphthalene in marine sediment. ISME J 2010, 4:1421-1430.

216. Carman KR, Bianchi TS, Kloep F: Influence of grazing and nitrogen on benthic algal blooms in diesel fuel-contaminated saltmarsh sediments. Environ Sci Technol 2000, 34:107-111.

217. Fleeger JW, Carman KR, Nisbet RM: Indirect effects of contaminants in aquatic ecosystems. Sci Total Environ 2003, 317:207-233.

218. Gertler C, Gerdts G, Timmis KN, Golyshin PN: Microbial consortia in mesocosm bioremediation trial using oil sorbents, slow-release fertilizer and bioaugmentation. FEMS Microbiol Ecol 2009, 69:288-300.

219. Cappello S, Denaro R, Genovese M, Giuliano L, Yakimov MM: Predominant growth of Alcanivorax during experiments on "oil spill bioremediation"in mesocosms. Microbiol Res 2007, 162:185-190.

220. Cochran PK, Kellogg CA, Paul JH: Prophage induction of indigenous marine lysogenic bacteria by environmental pollutants. Mar Ecol Prog Ser 1998, 164:125-133.

221. Rosenberg E, Bittan-Banin G, Sharon G, Shon A, Hershko G, Levy I, Ron EZ: The phage- driven microbial loop in petroleum bioremediation. Microb Biotechnol 2010, 3:467-472.
222. Lu Z-M, Deng Y, Van Nostrand JD, He Z-L, Voordeckers J, Zhou A-F, Lee YJ, Mason OU, Dubinsky EA, Chavarria KL, Tom LM, Fortney $\mathrm{L}$, Lamendella $\mathrm{R}$ Jansson JK, D'haeseleer P, Hazen TC, Zhou J-Z: Microbial gene functions enriched in the Deepwater Horizon deep-sea oil plume. ISME J 2012, 6:451-460

223. Hazen TC, Dubinsky EA, Desantis TZ, Andersen GL, Piceno YM, Singh N, Jansson JK, Probst A, Borglin SE, Fortney JL, Stringfellow WT, Bill M, Conrad ME, Tom LM, Chavarria KL, Alusi TR, Lamendella R, Joyner DC, Spier C, Baelum J, Auer M, Zemla ML, Chakraborty R, Sonnenthal EL, D'haeseleer P, Holman HY, Osman S, Lu Z, Van Nostrand JD, Deng Y, Zhou J, Mason OU: Deep-sea oil plume enriches indigenous oil- degrading bacteria. Science 2010, 330:204-208.

224. Herrick JB, Stuart-Keil KG, Ghiorse WC, Madsen EL: Natural horizontal transfer of a naphthalene dioxygenase gene between bacteria native to a coal tarcontaminated field site. Appl Environ Microbiol 1997, 63:2330-2337.

225. Top EM, Springael D, Boon N: Catabolic mobile genetic elements and their potential use in bioaugmentation of polluted soils and waters. FEMS Microbiol Ecol 2002, 42:199-208.

226. Cuny P, Miralles G, Cornet-Barthaux V, Acquaviva M, Stora G, Grossi V, Gilbert $\mathrm{F}$ : Influence of bioturbation by the polychaete Nereis diversicolor on the structure of bacterial communities in oil contaminated coastal sediments. Mar Pollut Bull 2007, 54:452-459.

227. Gilbert F, Stora G, Desrosiers G, Deflandre B, Bertrand J, Poggiale J, Gagne J: Alteration and release of aliphatic compounds by the polychaete Nereis virens (Sars) experimentally fed with hydrocarbons. J Exp Mar Biol Ecol 2001, 256:199-213

228. Grossi V, Massias D, Stora G, Bertrand JC: Burial, exportation and degradation of acyclic petroleum hydrocarbons following a simulated oil spill in bioturbated Mediterranean coastal sediments. Chemosphere 2002, 48:947-954.

229. Hickman ZA, Reid BJ: Earthworm assisted bioremediation of organic contaminants. Environ Int 2008, 34:1072-1081.

230. International Maritime Organization: Bioremediation in marine oil spills: guidance document for decision making and implementation of bioremediation in marine oil spills. London: IMO Publishing; 2004.

231. Lin Q, Mendelssohn IA: Determining tolerance limits for restoration and phytoremediation with Spartina patens in crude oil-contaminated sediment in greenhouse. Archiv Agrony Soil Sci 2008, 54:681-690.

232. Ramos JL, Duque E, van Dillewjin P, Daniels C, Krell T, Espinosa-Urgel M, Ramos-González M-I, Rodríguez S, Matilla M, Wittich R, Segura A: Removal of hydrocarbons and other related chemicals via the rhizosphere of plants. In Handbook of Hydrocarbon and Lipid Microbiology. Edited by Timmis KN, McGenity TJ, van der Meer JR, de Lorenzo V. Berlin Heidelberg: Springer; 2010:2575-2581.

233. Gallego JLR, Garcia-Martinez MJ, Llamas JF, Belloch C, Pelaez Al, Sanchez J: Biodegradation of oil tank bottom sludge using microbial consortia. Biodegradation 2007, 18:269-281.

234. Jacques RJS, Okeke BC, Bento FM, Teixeira AS, Peralba MCR, Camargo FAO: Microbial consortium bioaugmentation of polycyclic aromatic hydrocarbons in contaminated soil. Bioresour Technol 2008, 99:2637-2643.

235. Munoz R, Guieysse B: Algal-bacterial processes for the treatment of hazardous contaminants: a review. Water Res 2006, 40:2799-2815.

236. Huang WE, Stoecker K, Griffiths R, Newbold L, Daims H, Whiteley AS, Wagner M: Raman-FISH: combining stable-isotope Raman spectroscopy and fluorescence in situ hybridization for the single cell analysis of identity and function. Environ Microbiol 2007, 9:1878-1889.

237. Finzi-Hart JA, Pett-Ridge J, Weber PK, Popa R, Fallon SJ, Gunderson T, Hutcheon ID, Nealson KH, Capone DG: Fixation and fate of $\mathrm{C}$ and $\mathrm{N}$ in the cyanobacterium Trichodesmium using nanometer-scale secondary ion mass spectrometry. Proc Natl Acad Sci USA 2009, 106:6345-6350.

238. Orphan VJ: Methods for unveiling cryptic microbial partnerships in nature. Curr Opin Microbiol 2009, 12:231-237.

239. Klitgord N, Segre D: Ecosystems biology of microbial metabolism. Curr Opin Biotechnol 2011, 22:541-546.

\section{doi:10.1186/2046-9063-8-10}

Cite this article as: McGenity et al:: Marine crude-oil biodegradation: a central role for interspecies interactions. Aquatic Biosystems 2012 8:10. 